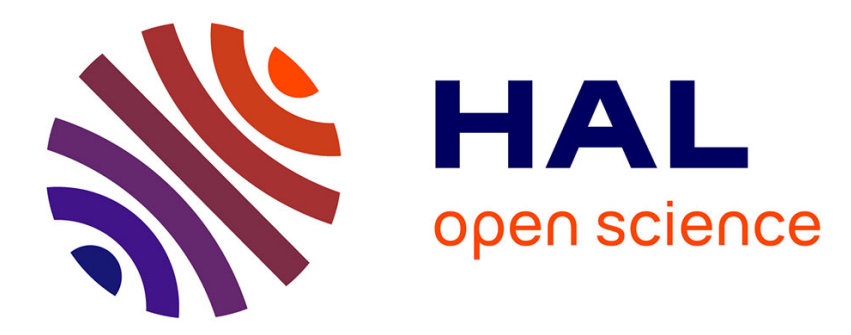

\title{
Dévots et Renonçants: L'autre Catégorie de Forgeurs de Hadiths
}

\author{
Lahcen Daaïf
}

\section{To cite this version:}

Lahcen Daaïf. Dévots et Renonçants: L'autre Catégorie de Forgeurs de Hadiths. Arabica, 2010, 57, pp.201 - 250. 10.1163/157005810X502646 . hal-02405096

\section{HAL Id: hal-02405096 \\ https://hal.science/hal-02405096}

Submitted on 19 Dec 2019

HAL is a multi-disciplinary open access archive for the deposit and dissemination of scientific research documents, whether they are published or not. The documents may come from teaching and research institutions in France or abroad, or from public or private research centers.
L'archive ouverte pluridisciplinaire HAL, est destinée au dépôt et à la diffusion de documents scientifiques de niveau recherche, publiés ou non, émanant des établissements d'enseignement et de recherche français ou étrangers, des laboratoires publics ou privés. 


\title{
Dévots et Renonçants : L'autre Catégorie de Forgeurs de Hadiths
}

\author{
Lahcen Daaif \\ EPHE-IRHT (CNRS)*
}

\section{Résumé}

Dès le premier siècle de l'hégire, pour s'imposer comme la seule voie légitime qui représente fidèlement l'islam contre les familles religieuses rivales, notamment le šíi isme et le hāriğisme, le sunnisme, comme ces derniers, a dû largement user des traditions prophétiques. Néanmoins, les règles qu'il érigera pour fonder cette nouvelle matière de connaissance religieuse ne verront le jour qu'un siècle plus tard. Suite aux rivalités politico-religieuses qui les avaient suscitées en partie, une fois développées et réorganisées progressivement en système de contrôle, ces règles allaient s'appliquer à toutes transmissions de traditions, sans en excepter celle de garants sunnites eux-mêmes. Au sein de celle-ci, certains rapporteurs de hadiths, d'une prolixité impressionnante, particulièrement versés dans le renoncement $(z u h h \bar{a} d)$ et la dévotion cultuelle ('ubbäd), se sont révélés de peu de foi, voire des menteurs notoires; raisons suffisamment convaincantes pour qu'ils soient catalogués, par des critiques farouchement fidèles au traditionnisme, comme une catégorie distincte de transmetteurs indigne de confiance. Leurs hadiths, tant au niveau des matns qu'au niveau des isnāds, tout au long des trois générations successives des salafs, ont été scrutés de très près, puis évalués et enfin décrétés impropres à la transmission (matrūk). En effet, la "forgerie" des hadiths, qui était de mise dans ce milieu, ne laissait pas de s'accentuer pour devenir un art de subterfuge dont se réclamaient ouvertement, dans la noble intention de servir la communauté sunnite, de notoires "renonçants".

\section{Mots-clés}

Renoncement $(z u h d)$, dévot, mystique, hadith, forgerie ( $w a d$ ), hérésiographie sunnite, la critique des autorités ( $i l m$ al-riğăl).

* Cet article est la version définitive de ma contribution à la journée d'études sur «Le hadịt: histoire, conceptions, usages», organisée, le 16 juin 2005, à EPHE/section religieuse, par M.H. Benkheira dont je salue l'initiative. Je tiens également à lui renouveler mes remerciements pour sa lecture attentive de la première version de ce travail, et pour les pertinents conseils qu'il m'a prodigués. Mes remerciements vont aussi à $\mathrm{M}^{\text {lle }}$ Jacqueline Sublet, grâce à qui ce travail a pu être repris de nouveau et mené à son terme. 
Vous, tous les sages illustres, vous avez été les serviteurs du peuple, et de la superstition du peuple - et non les serviteurs de la vérité. Et c'est précisément pourquoi on vous payait le tribut du respect ${ }^{1}$.

\section{Introduction}

Commençons tout d'abord par rappeler que les liens étroits entre traditionalisme $e^{2}$ et ascétisme, dès la fin du premier siècle de l'Islam, étaient une réalité historique indubitable, bien que les fils ténus de la trame politico-religieuse qui les sous-tendait restent encore fort complexes à démêler. En effet, à partir du moment où une approche analytique favorise a priori un type de facteurs historiques sur un autre, elle s'avoue dans l'incapacité de rendre compte de cette complexité, dans la mesure où elle ne fera que transiger arbitrairement pour un aspect au détriment d'un autre. En vain chercherait-on à saisir le fonctionnement qui présidait au mécanisme de cette corrélation du traditionalisme et de l'ascèse dans sa forme globale, quand bien même identifierait-on la genèse du traditionalisme au courant ascétique primitif. Cependant, le seul fait historique avéré est qu'au tournant du $\mathrm{II}^{\mathrm{e}} / \mathrm{VIII}^{\mathrm{e}}$ siècle, les contours autrefois estompés de cette corrélation vont nettement se dessiner et se détacher progressivement de l'ensemble de relations d'affinité entre les diverses formations et courants religieux. Par conséquent, ces deux principaux courants, engagés dans un seul et même idéal religieux communautaire, constituaient un bloc plus au moins homogène en rapport de rivalité avec les factions musulmanes adverses dont il ne partageait pas les doctrines religieuses ni les positions politiques.

Avant d'entamer cette étude, nous devons nous attarder un moment sur le $z u h d^{3}$, pour expliciter ce que nous entendons par cette notion dont le sens multiple, parce qu'extensif et fuyant à la fois, est généralement très difficile à cerner. Pour ce faire, insistons tout d'abord sur le fait que le $z u h d$ ne saurait se résumer au sens commun que se plaisent à lui donner les juristes formalis-

${ }^{1}$ Friedrich Nietzsche, Ainsi parlait Zarathoustra, trad. G.-A. Goldschmidt, Paris, Au Sans Pareil éditeurs («La bibliothèque des chefs-d'œuvre»), 1996, p. 115.

${ }^{2}$ Nous entendons par ce terme le courant religieux primitif qui s'était constitué exclusivement autour de la pratique vivante du Prophète (sunna), et qui fut à l'origine du traditionnisme (ahl al-hadit ), avec lequel il ne faut surtout pas le confondre.

${ }^{3}$ Pour plus d'informations, voir Leah Kinberg, "What is meant by zuhd», SI, LXI (1985), principalement les définitions spécifiques qu'elle propose pour cerner le $z u h d$ (p. 31-40) et ses liens caractéristiques avec le wara', le scrupule religieux (p. 41-3). Pour une vision générale se reporter à l'étude de Muhammad Sghir Janjar, «La tradition ascétique en islam. Le Zuhd: doctrine et technique du renoncement", Études Maghrébines, XII, (2000), p. 3-11. 
tes, à savoir qu'il consiste en un renoncement ordinaire aux choses matérielles de la vie, d'où résulterait un état visible d'indigence volontaire, comme en témoigne la vie austère de la plupart des figures marquantes du zuhd primitif. En second lieu, nous devons nous garder de trop exagérer l'identification de son principe de base avec le principe de détachement (tağrìd), aussi absolu soit-il, de la vie d'ici-bas au profit de la vie future, tout en étant d'avis que ce détachement en constitue naturellement l'un des aspects majeurs du fait de la notion de tawakkul, d'abandon à la volonté de Dieu qu'il implique. Et s'il devait y avoir un sens qui figurerait le lieu du zuhd à cette époque primitive qui nous occupe ici, il s'étendrait entre deux limites, celle du renoncement et celle du détachement. Et c'est de la sorte, comme dimension aux limites relativement fixes, que nous sommes en droit de le penser tel un horizon dans lequel prédomine un singulier état intérieur de sagesse $a b$ intra. La conduite de vie du sujet croyant, dans sa double facette d'homme à la fois sociable, comme il convient à un individu exemplaire dans ses rapports avec ses semblables, et en même temps enclin au repli sur soi-même dans sa vocation interne, n'en altère pas le fondement. Au contraire, cette conduite ainsi délimitée participe de la substance spirituelle de celui-ci en diversifiant les formes ascétiques de son expression. On s'aperçoit dès lors que le zuhd serait plutôt à concevoir comme un état d'esprit dont la stabilité s'enracine dans un mode d'être détaché, qui puise dans une pensée à caractère religieux articulée sur un système de vie pratique où s'entrecroisent l'ensemble de valeurs morales et spirituelles auxquelles le sujet « renonçant» (zāhid) se veut fidèle.

Doit-on en conclure que les personnages ascético-mystiques de l'Islam sont définitivement inappropriés à la typologie weberienne de l'ascèse? Évidemment qu'une telle conclusion est à nuancer. Déjà dans son étude comparative sur Ibn Hanbal (m. 241/855) et le mystique Bišr al-Hāfì (m. 227/841-2), Michael Cooperson a su démontrer le contraire, en insérant ces deux protagonistes respectivement dans l'ascèse intramondaine inner-worldly ascetic et l'ascèse extramondaine world-rejecting mystic ${ }^{4}$. Pourtant, comme nous le verrons plus loin, la complexion particulière de certains renonçants ne peut pas se prêter à cette division bipartite aussi facilement que ces deux personnages clefs de l'ascèse. Celle-ci repose le problème des limites de ce partage d'ordre sociologique, fondé sur le rapport de l'ascète au monde réel. Même s'il se dégage de cette typologie un paradigme qui justifie la raison pour laquelle tel ou tel ascète doit être inscrit dans un type d'ascèse plutôt que dans l'autre, il laisse à l'appréciation subjective le soin de déterminer laquelle des deux

${ }^{4}$ Cf, Michael Cooperson, "Ibn Hanbal and Bishr al-Hāfī. A Case Study in Biographical Traditions", SI, LXXXVI/2, (1997), p. 91. Sur les types weberiens respectivement en allemand innerweltliche und ausserweltliche Askese, voir Max Weber, Sociologie des religions, trad. G.-P. Grossein, Paris, Gallimard, 1996, p. 150, 212-30, 310 et passim. 
tendances est plus à même de correspondre à l'identité comportementale des ascètes concernés. Aussi, sommes-nous confrontés, d'une part, à des ascètes ressortissant aux deux types weberiens d'ascèse à la fois, faute de repères différentiels précis, et d'autre part à des ascètes d'un genre particulier qui peuvent alterner entre les deux registres à diverses périodes de leur vie. Ils sont nombreux ceux d'entre eux qui nous offrent, tant par leur conduite et leur projet de vie que par leur rapport individuel à la religion, au pouvoir politique et à la société dans laquelle ils évoluent en général, une combinatoire de variantes d'autant plus riche et variée qu'il en serait arbitraire de prétendre les identifier en bloc à l'un ou à l'autre type d'ascèse du schéma binaire que propose Weber.

Pour ce qui est du substantif zuhd aux premiers temps de l'islam, il faut bien emboîter le pas à Denis Gril, quand il fait remarquer, à juste titre, que celui-ci est «le terme qui revient le plus souvent pour caractériser la spiritualité des deux premiers siècles ${ }^{5}$ ", parce qu'il renferme, en quelque sorte, les germes mystiques d'un certain esprit de soufisme qui allait éclore quelques temps plus tard ${ }^{6}$. Nous serons amené à inclure, par voie de conséquence, dans la sphère des renonçants que nous envisageons d'étudier, les autorités religieuses qui sont à la fois de tendance ascétique prononcée et de facture plus au moins ésotérique.

Quant au terme de muta'abbid, dérivé de 'ibāda (i.e. adoration, culte rituel rendu à Dieu), que nous avons rendu approximativement par le vocable "dévot», comme la majorité des islamisants, il renvoie strictement au statut d'un croyant rompu à l'adoration de Dieu au moyen de l'accomplissement des œuvres cultuelles prescrites par la religion. Contrairement au statut de $z \bar{a} h i d$ que nous avons évoqué plus haut, d'un point de vue sociologique, la situation du dévot, elle, confine plutôt à l'isolement et à la retraite ('uzla, balwa), deux aspects corrélatifs du «renonçant». Il se peut que cet isolement s'apparente, sous certains traits, à une forme plus au moins atténuée, mais rarement accentuée, du monachisme chrétien. En règle générale, celui que l'on désigne par mutáabbid ou nāsik (pl. nussāk $k)^{7}$ n'est pas forcément étranger au climat du renoncement ambiant de son milieu, dans la mesure où son caractère dévotionnel est susceptible de présenter des recoupements avec cette incommensurabilité du champ du zuhd dont on ne signalera jamais assez la

5 D. Gril, "Les débuts du Soufisme», in A. Popovic \& G. Veinstein (dir.), Les Voies d'Allah, Paris, Fayard, 1996, p. 31.

${ }^{6}$ Cf. Christopher Melchert, "The transition from asceticism to mysticism at the middle of the ninth century C.E.», SI, LXXXIII/1 (1996), spécialement p. 52-64.

7 Notons que la majorité des disciples d'al-Hasan al-Baṣrī, généralement des zuhhād, est mentionnée, dans les recueils hagiographiques, comme des 'ubbād (sing. 'ābid) ou des nussāk. 
portée de son rôle ni l'étendue de son sens. D'autre part, nonobstant le nombre considérable de dévots parmi les transmetteurs de hadiths à tendance ascétique indéniable, il ne faut pas perdre de vue que c'est plutôt la dévotion cultuelle qui prime chez eux les qualités à caractère renonciatif ${ }^{8}$. Toujours est-il que ces deux orientations spécifiques de la dévotion et du renoncement qui s'entrecroisent et divergent selon qu'elles donnent la précellence à tel ou à tel ordre d'engagement religieux, se rejoignent en un point nodal, celui du dénuement ( faqr).

\section{Le zubd au sein du sunnisme}

Le renoncement n'est évidemment pas l'apanage de la famille sunnite traditionniste, puisqu'il a trouvé également écho au sein des autres formations doctrinales de l'Islam presque à la même époque, ainsi chez les Šîi ites et les Hāriğites etc. Mais la tendance au renoncement est particulièrement significative dans les débuts de l'organisation du mouvement sunnite, qui a pris son essor en Irak, précisément à Bașra, la ville où s'est concentrée la fine fleur la plus dynamique des renonçants $(z u h h \bar{a} d)$. Ce sont eux les hommes du parti religieux, supposés avoir été à l'origine du regroupement sunnite qui se faisait appeler alors les Gens de la Tradition et de la Communauté (ahl al-Sunna $\left.w a-l-G a m \bar{a}^{c} a\right)^{9}$, parti dans lequel le théologien hérésiographe 'Abd al-Qāhir al-Bağdādī (m. 429/1037) pensait reconnaître la secte sauvée (al-firqa l-nāğiya), la dernière des soixante-treize sectes de l'islam, ainsi qu'en fait état le hadith célèbre ${ }^{10}$. Les premiers hommes de ce courant prônaient aussi bien dans leur discours que par leur comportement, une conduite ascétique

${ }^{8}$ Est plus significatif à ce sujet le personnage de Hassān b. Abī Sinān. Il revient souvent sous les traits d'un mutáabbid, mais rarement sous l'épithète de zāhid, alors qu'il était un disciple d'al-Bașrī, cf. Ibn Hağar, Tahdīib al-tahdīib, Haydarābād, établi par 'Abd al-Raḥmān b. Yahyā 1-Mu'allimī l-Yamānī, Dār al-ma ārif al-nizāmiyya, 1325/1907-1327/1909, réimp. Beyrouth, Dār Ṣādir, s.d., II, p. 249-50, n 454. Le personnage d'un autre zāhid, également disciple d'alBașrī, Tāāit b. Aslam al-Bunānī (m. 127/745), est expressément différencié de ses contemporains «renonçants" par le superlatif de a'bad, "celui qui s'adonne le plus à l'adoration de Dieu", cf. Ibn Hanbal, Kitāb al-Zuhd, éd. Yahyyā b. Muhammad Sūs al-Azharī, $2^{\mathrm{e}}$ éd., al-Manșūra, Dār Ibn Rağab, 2003, p. 518.

9 Consacrée dans l'Islam sunnite, cette expression renvoie au premier groupe sunnite qui préconisait une doctrine dogmatique de "juste milieu entre les thèses contraires qui s'affrontent", cf. H. Laoust, Essai sur les doctrines sociales et politiques de Takì-d-Din Aḥmad B. Taimìya: canoniste hanbalite né à Harrān en 661/1262, mort à Damas en 728/1328, Le Caire, I.F.A.O., 1939, p. 227.

10 'Abd al-Qāhir al-Bag̀dādī, al-Farq bayna l-firaq wa-bayān al-firqa l-nāğiya minhum, Beyrouth, Dār al-āfāq al-ğadīda, 1400/1980, p. 19-20. 
exemplaire en ce bas-monde (duny $\bar{a})$, et exhortaient leurs contemporains au double détachement temporel et spirituel.

Il est donc fort probable que le courant ascétique, qui est à considérer du moins en partie, comme une forme de réaction à l'état schismatique dans lequel sombrait le monde musulman d'alors, soit à l'origine de la formation du parti sunnite qui lui emprunte ses principes éthiques pour mettre en place l'assise morale et religieuse du sunnisme à venir. Et partant, les valeurs et les principes à caractère ascétique se verront, dans leur grande majorité, intégrés dans le corpus sunnite en gestation pour ensuite ne plus faire qu'un avec le noyau dur de son ethos. C'est pourquoi il nous semble plus correct d'envisager l'histoire de ces deux grands mouvements religieux, sinon dans un rapport d'identité, du moins dans une relation de complémentarité très rapprochée, et d'éviter par conséquent d'y voir deux courants parfaitement distincts, voire même antinomiques. En somme, mais principalement à cette époque, il s'agit bel et bien d'un seul et même corps religieux dans lequel l'ordre spirituel, par le biais de l'action du renoncement collectif, vient se combiner à la constitution doctrinale et juridique pour donner naissance à la formation politico-religieuse dénonçant l'illégitimité de ses rivaux.

Au fur et à mesure que le courant sunnite gagnait du terrain aux dépens de ses rivaux, de son côté la pratique de la transmission de hadiths, en se généralisant, voyait ses techniques de diffusion se développer à toute vitesse. En outre, l'évolution fulgurante de cette nouvelle matière religieuse qu'est le hadith nécessitera à son tour l'élaboration d'un nouveau système de contrôle, destiné, après leur identification, à évaluer la sincérité et l'intégrité des garants de hadiths (rāwī, pl. ruwāt). C'est à l'issue de ces deux étapes historiques du développement du hadith en tant que matière et discipline autonomes que le regard réprobateur des parangons du sunnisme ne se portera plus seulement sur des objets extérieurs à sa sphère. Jadis exclusivement dirigé vers le dehors pour accuser de l'index moralisateur les représentants des courants concurrents, l'œil examinateur du sunnisme allait dorénavant scruter de près son propre état intérieur, et enclencher aussitôt le passage à l'étamine de ses propres membres. D'une certaine manière, le sunnisme promouvra sur lui-même le contrôle strict qu'il a tant recommandé d'exercer sur les autres, afin de mettre corrélativement en pratique l'une des plus essentielles consignes de l'ascèse, à savoir l'examen de soi. Témoignant de toute évidence d'un souci de soi qui renchérit sa caution de la vérité dont il se veut porteur, désormais il ne se contentera plus de mettre en examen seulement l'intégrité des transmetteurs étrangers à son cercle d'influence, puisque celle de ses propres membres s'est révélée à ses yeux elle-même défaillante.

C'est par ce retour progressif sur soi-même que les critiques vont prendre conscience de l'existence d'un type de garants, internes au sunnisme, qui n'ont 
éveillé jusque-là que peu de soupçons. Il aurait décidément réussi à passer entre les mailles du filet, tendu par le système critique du sunnisme encore en formation. Ce sont souvent des hommes de bonne foi, exceptionnellement vertueux, tout dévoués à la cause sunnite, néanmoins enclins au mensonge, parce que peu regardants sur l'origine des hadiths qu'ils transmettaient du moment que ceux-ci allaient dans le sens de leurs aspirations, et ne contredisaient pas leur perception de la vraie religion ${ }^{11}$. Alors qu'au départ les garants avaient été amenés à forger des hadiths pour des raisons d'ordre dogmatique, politique, et parfois clanique ('asabiyya) ${ }^{12}$, celles qu'invoquaient ces nouveaux forgeurs bien intentionnés étaient motivées par la volonté sincère d'orienter vers la rectitude leurs coreligionnaires sunnites de sorte à améliorer leurs connaissances religieuses.

On voit apparaître ici en filigrane la marque de partage entre deux manières d'appréhender la doctrine sunnite: d'une part, tandis que l'on se voulait fidèle à une religion, telle qu'on se la représentait dans son essence originelle, c'est-à-dire affranchie de tous apports extérieurs ou luttant contre l'effort de réflexion individuelle, d'autre part, dans le but de la parfaire, on tendait à donner la priorité à des fins morales et spirituelles au prix même du mensonge $^{13}$. Dans le cas où ce phénomène aurait eu des antécédents caractérisés dans le passé sunnite, nous serions amené à nous interroger sur les premiers personnages renonçants qui l'incarnaient pour nous faire une idée cohérente de ce qu'ils étaient et représentaient réellement. Pourquoi s'étaient-ils investis consciencieusement dans cette voie extra-légale au jugement des sunnites? Dans quelle mesure serait-il pertinent de les relier aux générations postérieures d'ascètes qui auraient transmis à leur tour des hadiths douteux? En nous en tenant historiquement à ce cadre-là, il est inutile de nous attarder plus avant sur les Suivants étrangers à la sphère du $z u h d$, quand bien même leur

11 Ibn al-Ğawzì les range dans la cinquième catégorie que composent trois parties dont la dernière est subdivisée en sept cas distincts, cf. id., Kitāb al-Mawdū'āt, éd. 'Abd al-Rahmān Muḥammad 'Uțmān, Médine, al-Maktaba l-salafiyya, 1966-68/1386-88, I, p. 36-48. Pour la présentation du schéma introductif établi par Ibn al-Ğawzī, dans son livre al-Mawdī àt, nous renvoyons à l'article d'Albrecht Noth, "Common Features of Muslim and Orientalism Hadìth Criticism ", in Hadìth Origins and development, éd. Harald Motzki, Ashgate, 2004.

12 Ibn al-Ğawzī, K. al-Mawdǖàt, I, p. 37-9.

13 Ibn al-Ğawzī a décrit avec précision ce type de forgeurs de hadiths qui, dès qu'un propos leur semblait juste et bon (hasan) dans sa teneur, s'empressaient de lui fabriquer une chaîne de garants sur mesure par esprit de piété. En effet, certains transmetteurs préconisaient l'invention des isnäds dans ce sens, comme en témoigne la déclaration faite par le savant damascène Muḥammad b. Sa īid al-Šāmī, qui fut taxé d'hérésie. Cf. le quatrième cas de la subdivision évoquée, id., K. al-Mawdǖàt, I, p. 41. 
crédibilité serait-elle contestée par les critiques traditionnistes, à l'instar par exemple de 'Ikrima (m. 105/722) mawlā (client affranchi) d'Ibn 'Abbās ${ }^{14}$.

\section{Les devanciers ont-ils ouvert la voie?}

Il est vrai qu'au premier siècle de l'islam les règles élémentaires pour transmettre les hadiths, telles qu'elles seront plus tard élaborées, étaient quasi inexistantes. Même les chaînes de garants semblaient être, dans un premier temps, une preuve facultative, bien loin de figurer une instance prioritaire ${ }^{15}$. Si l'on s'en réfère à l'historiographie musulmane, il appert qu'il s'agissait moins de l'isnād à proprement parler que de ce qu'il conviendrait d'appeler ses prémices ${ }^{16}$, puisque les vérifications ne se portaient essentiellement que sur les hommes présumés à la source des traditions prophétiques transmises. Néanmoins, quoiqu'encore vague et imprécis, nul doute qu'il y avait bien un critère commun de validité qui fondait entièrement le processus de sélection, et qui consistait tout simplement à appartenir à la famille sunnite ${ }^{17}$. De même que le zuhd se détermine partiellement comme phénomène réactif à

14 Selon Ibn Sa'd (m. 230/845), malgré l'étendue de son savoir religieux et la quantité impressionnante de ses transmissions, ses hadiths n'ont pas valeur probante, cf. id., al-Ṭabaqāt al-kubrā, Beyrouth, Dār Ṣādir, 1968/1388, réimp. Beyrouth, Dār Bayrūt, 1980/1400, V, p. 293.

${ }^{15}$ Voir l'introduction d'Ibn Hağar à son Lisān al-mīzān, Haydarābād, Dāirat al-ma'ārif al-nizāmiyya, 1329-1331, I, p. 7.

${ }_{16}$ La question de la datation de l'isnād continue encore de diviser les orientalistes islamisants: I. Goldziher et J. Schacht, par exemple, pensent que la naissance de l'isnäd devait se situer vers la fin de la première moitié du VIII siècle, alors que G. Schoeler propose le dernier tiers de ce même siècle, dans, Écrire et transmettre dans les débuts de l'islam, Paris, PUF, 2002, p. 128. D'un autre côté, nous avons N. Abbott, F. Sezgin, J. Horovitz et à leur suite G.H.A. Juynboll qui croient pouvoir faire remonter l'apparition de l'isnäd d'un demi-siècle, c'est-à-dire vers la fin du VII ${ }^{e}$ de l'ère commune. Ce qui correspondrait aux informations fournies par les sources prosopographiques musulmanes, voir G.H.A. Juynboll, "The Date of the Great Fitna», Arabica, XX/2 (1973), p. 159.

${ }^{17}$ Le propos constamment cité à ce sujet est attribué à Ibn Sīrīn (m. 110/728), voir entre autres, Ibn Hanbal, Kitāb al-'Ilal wa-ma'rifat al-riğāl bi-riwāyat 'Abd Allāh b. Ahmad b. Hanbal, éd. Wașī llāh 'Abbās, Beyrouth, al-Maktab al-islāmī, 1408/1988, II, p. 559, § 3640; aussi l'introduction de Muslim b. al-Hağğăğ à son Șaḩ̄ḥ, éd. critique Muhammad Fu'ād 'Abd al-Bāqī, Le Caire, Dār ihyā̄' al-kutub al-'arabiyya, 1375-6/1955-6, p. 15; Ibn Abī Ḥāim al-Rāzī, Kitāb al-Ğarh wa-l-ta'dīl, $2^{e}$ éd., 'Abd al-Raḥmān b. Yahyā l-Mu'allimī l-Yamānī, Haydarābād, 1973, II, p. 28; Ibn Hağar, Lisān, I, p. 7; Abū Nu'aym al-Iṣfahānī, Hilyat al-awliyāà wa-țabaqāt al-asfyyà, Le Caire, 1932-38, réimp. Beyrouth, Dār al-kutub al-ilmiyya, 1988, II, p. 278; le

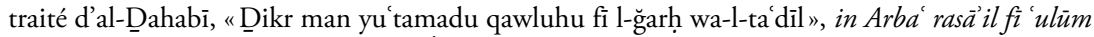
al-ḥadịt, éd. 'Abd al-Fattāḥ Abū Gudda, Beyrouth, Dār al-Qurān al-karīm, 1400/1980, p. $143,157-213,159$. 
l'état de trouble politico-religieux antérieure, de même l'isnād voit sa position s'affermir au rythme de l'intensité de ces mêmes troubles à l'époque suivante. Ceci étant, nous n'envisageons pas la naissance du premier comme étape nécessaire à la venue au monde du second. Et pour arriver au terme de cette interprétation, nous dirions que l'isnäd incarne le zuhd dans sa seconde réaction aux discordes récurrentes ( fitna, pl. fitan) et aux dissidences intestines qui sévissaient dans la communauté ${ }^{18}$.

Sans qu'ils aillent jusqu'à parler ouvertement de mensonge volontaire, ni dénoncer une invention délibérée de traditions, les experts de la période classique en matière de critique des autorités se sont aperçus que d'illustres personnages du sunnisme anciens ont eu, à des degrés divers, recours à des méthodes de transmission peu orthodoxes tant au niveau des contenus des traditions (matn, pl. mutūn) qu'à celui des chaînes de garants (isnäd, pl. asānìd). En dépit de cet état de choses, on remarque que les plus éminents d'entre les Suivants (kibār al-tābìinn) sont avantagés sur les tardifs, car ils bénéficient d'une certaine manière d'un traitement de faveur. Cela est induit par la règle en vigueur chez les critiques comme chez tous les traditionnistes, d'après laquelle les Suivants doivent être considérés, dans leur grande majorité, comme étant des "hommes de confiance (țiquat), sincères (sädiqün), dotés de clairvoyance quant à ce qu'ils transmettent ${ }^{19}$." Al-Hākim al-Nīsābūrī (m. 405/1014) entend donc les différencier de leurs successeurs, dans la mesure où «[...] leur but, en exerçant la transmission (riwäya), était d'appeler [les gens] à Dieu [...] tandis que les transmetteurs des générations suivantes, en s'y adonnant, visaient divers objectifs ${ }^{20}$.» Ce privilège leur revient de droit pour la bonne raison que leur antériorité chronologique leur a permis de côtoyer de près les Compagnons du Prophète, lesquels sont, par principe de foi, les seuls transmetteurs à être définitivement dispensés de toute espèce

18 Dans l'ensemble, il n'est pas aisé de déterminer, des informations fournies par les sources, de quelle fitna au juste il est question dans le propos attribué à Ibn Sīrīn. G.H.A. Juynboll soutient qu'il ne s'agit pas de l'assassinat du troisième Calife 'Uțmān b. 'Affān (m. 35/656) qui n'aura été cité comme fitna qu'à la seconde moitié du deuxième siècle de l'hégire, cf. id., "The Date», p. 152. En prenant en compte la date de la mort d'Ibn Sīrīn (m. 110/728), il y aurait lieu de considérer la cinquième fitna comme étant celle de 'Abd Allāh b. al-Zubayr qui fut exécuté par ordre d'al-Hağgaăğ à Médine en 73/692, cf. id., "The Date», p. 159. Dix années plus tard, et suite aux remarques de J. van Ess sur la question, G.H.A. Juynboll réitère son point de vue dans son article «Muslim's introduction to his Sabịh, Translated and Annotated with an Excursus on the Chronology of Fitna and Bid 'a", Jerusalem Studies in Arabic and Islam, V, 1984, p. 263-311, repris dans son livre Studies on the Origins and Uses of Islamic Hadith, Aldershot, Variorum, 1996, III, p. 307.

19 Al-Dahabī, "Dikr man yu tamadu qawluhu», p. 160.

${ }^{20}$ Al-Ḥākim al-Nīsābūrī, Ma'rifat 'ulūm al-ḥadīt, éd. Mu'aẓ̧am Husayn, Beyrouth, Dār al-āfāq al-ğadìda, 1400/1980, p. 104. 
d'évaluation critique ${ }^{21}$. Mais comme il devait bien y avoir quelques observations à formuler au sujet de la qualité de la transmission d'un de ces Suivants distingués, il y aurait tout intérêt à ce qu'elles soient moins abruptes et assez modérées. Par conséquent le pli est pris, en ce sens que les conclusions consignées de ces évaluations, à quelques rares exceptions près, empruntent souvent des expressions tempérées, et se servent de formules consacrées dans lesquelles prévaut naturellement la pondération, et où l'on use d'un style, quoique technique comme le veut la discipline, empreint de déférence, gage de respect dû au rang supérieur dans lequel on tient ces transmetteurs vénérés de la première génération. Dans ce qui suit, nous tâcherons de passer en revue les opinions courantes portées sur la qualité de transmission de deux personnages-clés du traditionnisme primitif, que l'historiographie musulmane dépeint comme des pionniers de l'ascèse naissante et des maîtres à penser en matière de piété.

L'exemple dont on est souvent informé en premier est celui du célèbre jurisconsulte $(m u f t \bar{\imath})$ et ascète de la première génération, le Suivant $\left(t \bar{a} b i^{\prime} \bar{\imath}\right)$ al-Hasan al-Bașrī (m. 110/728) auquel se rattachent les diverses tendances et courants religieux de l'islam sunnite, tant en théologie dogmatique (kalām) qu'en enseignement ésotérique ${ }^{22}$. En plus d'être un adepte reconnu de la pra-

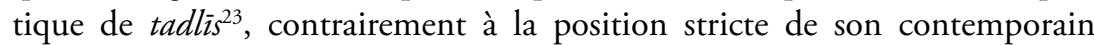

${ }^{21}$ Al-Rāzī, Kitāb al-Ğarh, I, p. 7; G.H.A. Juynboll, Muslim Tradition. Studies in Chronology, Provenance and Authorship of Early Hadith, Cambridge Univ. Press, Cambridge, Londres, New York, 1983, p. 190 sq.

${ }_{22}$ Cl. Cahen, L'Islam, Paris, Hachette, 1997, p. 104; J. Sauvaget, Historiens arabes. Pages choisies, traduites et présentées par - , Paris, Maisonneuve, 1946, p. 185, et c'est dans ce sens que Muṣlih S. Bayyūmī a intitulé son livre al-Hasan al-Bașrī min 'amäliqat al-fikr wa-l-zuhd wa-l-dàwa fì l-islām, Le Caire, Maktabat al-nahḍa, 1980.

${ }^{23}$ Celui qui en fait usage est appelé mudallis: faussaire, falsificateur, maquilleur. Lorsqu'il est question du tadlīs sans autre spécification, c'est de l'intervention sur le plan de l'isnäd dont il s'agit, bien que l'on qualifie du même nom l'invention d'un matn. Le premier cas est toléré sous certaines conditions, en revanche le second est strictement interdit. Sur les différentes catégories du tadlīs, voir al-Ḥākim al-Nīsābūrī, Márifat, p. 103-12; Abū 'Amr b. al-Ṣalāh, Muqaddimat [Ibn al-Ṣalāḥ], éd. 'Ā'iša bint al-Šāți', Le Caire, Dār al-ma'ārif ("Dahāāir al-'Arab», 44), 1410/1990, p. 230-36; Ibn Hağar, Tảrîf ahl al-taqdīs bi-marātib al-mawșūfìn bi-l-tadlìs, éd. 'A.S. al-Bandārī et M.A. 'Abd al-'Azīz, Beyrouth, Dār al-kutub al-ilmiyya, 1984/1405I, p. 24 sq. ; Ibn al-'Imād al-Hanbalī, Šadarāt al-dahab fì abuār man dahab, Le Caire, Maktabat al-Qudsī, 1350-1351/1931-1932, réimp. Beyrouth, 1399/1979, I, p. 222-23; aussi l'article de G.H.A. Juynboll, «Tadlīs», $E I^{2}$, X, p. 80-81.

Quant au tadlīs d'al-Bașrī, nous renvoyons entre autres à Šams al-Dīn al-Dahabī, Tạdkirat al-ḥuffāz, 4e éd., 'Abd al-Raḥmān b. Yahyā l-Mu'allimī, Haydarābād, Dāirat al-ma'ārif, 138890/1968-70, I, p. 72; id., Mìzān al-ítidāl fì má rifat al-riğăl, éd. 'Alī Muhammad al-Biğāwī, Beyrouth, Dār al-márifa, 1383/1963, I, p. 527; Helmut Ritter, "Hasan al-Bașrī», EI², III, p. 255; voir quelques-uns de ses hadiths dits relâchés dans Ibn Rağab, Ğàmi al-'ulüm wa-lhikam, éd. Šu 'ayb al-Arnā'ūt, \& alii, 1411/1991, I, p. 218, 342 et passim. 
Muhammad b. Sīrīn (m. 110/728) ${ }^{24}$, al-Bașrī n’était pas contre l'idée de tronquer une tradition prophétique, ou au contraire de l'augmenter par l'adjonction d'un bout (taraf) de discours, du moment que le sens initial de son contenu est préservé25. C'est pour cela qu'il recommandait même la mise en valeur du hadith par l'enjolivement de son matn, afin que la parole du Prophète fût distinguée et qu'elle eût plus d'effet. Mais il n'était apparemment pas le seul, dans le milieu traditionniste, à avoir ouvertement préconisé de recourir à un tel subterfuge. On nous signale, en effet, un procédé similaire que son contemporain 'Āmir b. Šarāhịil al-Ša ' bī (m. 104/722-3 ou 105/723-4), juriste et traditionniste également identifié comme mudallis ${ }^{26}$, reconnaissait avoir régulièrement pratiqué.

"Quand nous entendons un hadith de vous, lui aurait-on fait remarquer, nous y décelons une différence par rapport aux transmissions qui nous sont parvenues par d'autres autorités [pourquoi cela?]. Et al-Ša bỉ de répondre: "En effet, lorsqu'il [hadith] me paraît sous une forme dépouillée ('äriyan), je l'habille, mais sans y adjoindre une seule lettre". "Autrement dit, commente Abū l-Hilāl al-'Askarī (m. 395/1006), sans rien ajouter à son sens initial" " ${ }^{27}$.

Et pour cause, ce procédé n'était pas méconnu des divers milieux littéraires à cette même époque, où il était également observé, particulièrement en ce qui concerne l'enseignement et la transmission de la poésie. Il incombait aux transmetteurs des poèmes, avant de les diffuser, non seulement de les corriger sur le plan de la grammaire et de la métrique, de rendre intelligibles certains passages confus, mais aussi d'en améliorer les qualités artistiques et les propriétés linguistiques ${ }^{28}$.

En raison des largesses d'al-Bașrī en fait de transmission, toutes les traditions dites relâchées (marāsīl, sing. mursal) - à savoir celles qu'il avait transmises directement du Prophète sans passer par un Compagnon de celui-ci, dont il était censé les détenir ${ }^{29}$-, ont été déclassées du registre des preuves

${ }^{24}$ Ibn Sīrīn, quant à lui, non seulement ne partageait pas cet avis, mais il y était opposé. Il avait pour principe, outre de rendre fidèlement le sens du matn, de transmettre le hadith, autant que faire se peut, dans sa forme littérale, cf. Ibn Sa'd, al-Ṭabaqāt, VII, p. 194 : kāna yuhadditu l-ḥadīt 'alä ḥurūfihi, aussi G.H.A. Juynboll, Muslim Tradition, p. 52.

25 Ibn Sa'd, al-Ţabaqāt, VII, p. 159.

26 Son tadlīs se faisait principalement sur le compte du Compagnon 'Abd Allāh b. Mas'ūd et de la femme du Prophète 'Á'iša bint Abī Bakr, cf. al-Nīsābūrī, Ma' rifat, p. 111.

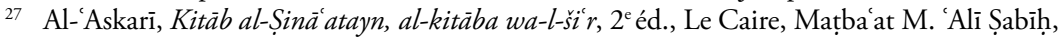
s.d., p. 218.

28 Pour plus détail voir G. Schoeler, Écrire, p. 18-26.

29 Pour les spécialistes en sciences du hadith, la tradition dite interrompue (munqati $i$ ) - qui pourrait aussi faire partie des marāsill d'après certains traditionnistes - et celle dite énigmatique (mu dil) qu'on lui assimile parfois, toutes deux ne concernent que les générations postérieures aux Suivants. Du point de vue de la terminologie des juristes et des théoriciens du droit, ces 
légales $(l \bar{a} \text { yuhtăğğ } b i h \bar{a})^{30}$. Cette question est devenue un thème récurrent dans toutes les biographies d'al-Bașrī, et plus amplement encore dans les monographies consacrées aux marāsīl, dont l'étude constitue l'une des disciplines-clés des sciences du hadith. Des générations successives de critiques qui se sont penchées sur le cas d'al-Bașrī, mis à part quelques divergences bénignes, les anciens comme les tardifs ont abouti à cette même conclusion selon laquelle ces marāsīl ne valent rien comme preuves légales ${ }^{31}$. Reste qu'en règle générale, le maintien de ces marāsīl est approuvé par ces mêmes critiques tant qu'ils traitent des valeurs morales, incitant à l'accomplissement d'actions vertueuses et favorisant la piété du caractère dans le rapport aux hommes comme à Dieu. C'est pour cette raison, de fil en aiguille, qu'ils ont concédé de créer, pour ce genre de hadiths qui se rattachent au Prophète par des chaînes de garants dépourvues de Compagnons, un statut conventionnel à la mesure des propos sentencieux se rapportant à l'édification morale et spirituelle de la communauté musulmane ${ }^{32}$.

Une sentence analogue n'a pas épargné les traditions relâchées d'un autre éminent savant et renonçant, réputé pour ses qualités ascétiques qui sont restées très célèbres, et dont on nous dit que la grande mosquée de La Mecque lui aurait fait office de domicile pendant une vingtaine d'années ${ }^{33}$. C'est de l'affranchi noir Abū Muslim 'Ațā’ b. Abī Rabāh (m. 114-5/732-3) dont il

deux types de hadiths sont appelés également mursal. Mais pour ce qui nous intéresse ici, référons-nous à Ibn al-Ṣalāh (m. 643/1245), dans sa Muqaddima, p. 202-03 où il définit le mursal comme suit: "[...] propos du grand Successeur ayant côtoyé plusieurs Compagnons [..], lorsqu’il déclare: "l'Envoyé de Dieu a dit" ". Voir sur le munqați, ibid., p. 613-15, sur le mu'dil, p. 616-29. La même définition est reprise par Abū Zakariyyā’ al-Nawawī (m. 676/1277), dans al-Suyūțī, Tadrīb al-rāwī fì šarh Taqrīb al-Nawāwī [sic], éd. Aḥmad 'Umar Hāšim, Beyrouth, Dār al-kitāb al-'arabī, 1405/1985, I, p. 160. Sur les deux premières formes de hadiths, cf. ibid.,

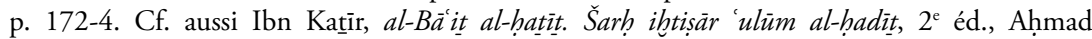
Muhammad Šākir, Beyrouth, Dār al-kutub al-ilmiyya, 1370/1951, p. 46.

${ }^{30}$ Cf. al-Dahabī, Siyar a'lām al-nubalā', éd. Šu ayb al-Arnāūt \& alii, Beyrouth, Mu’assasat al-risāla, 1401-1408/1981-1988, IV, p. 572; Ibn Hağar, Tahdīb, II, p. 266.

31 Cf. Abū l-Walīd al-Bāḡī, par exemple, qui recommande la vigilance notamment quand il s'agit des traditions relâchées d'al-Bașrī, cf. id., Iḥkām al-fușūl fì aḥkām al-ușūl, éd. M. AbdelMagid Turki, Beyrouth, Dār al-ġarb al-islāmī, 1407/1986, p. 337.

32 Cette opinion est commune à la plupart des grands critiques du hadith, tels qu'Ibn Hanbal, Ibn Abī Ḥātim al-Rāzī, Abū Zur'a l-Rāzī, Ibn al-Madīnī etc, cf. Ibn al-'Imād, Šadarāt, II, p. 98; Ibn al-Ğawzī, Talbìs Iblīs, Le Caire, Idārat al-țibā'a l-munīriyya, 1386 h., p. 124. Ibn Taymiyya a consacré un chapitre entier à cette règle à laquelle Ibn Hanbal était resté fidèle et

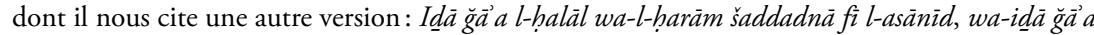
l-tarḡìb wa-l-tarhīb tasāhalnā fì l-asānìd, cf. id., 'Ilm al-ḥadīt, $2^{\mathrm{e}}$ éd., Dār al-kutub al-ilmiyya, 1409/1989, p. 55-7.

${ }^{33}$ Kāna l-masğgid firāšahu 'išrīna sana, cf. al-Dahabī, Tadkira, I, p. 98. 
s'agit, qui fut l'un des plus remarquables jurisconsultes $(m u f t \bar{l})^{34}$ et garants de hadiths qu'eût connus La Mecque depuis la disparition du Compagnon et cousin germain du Prophète 'Abd Allāh b. 'Abbās (m. 68/686-7), surnommé par la tradition le Docte de la communauté ( habr al-umma) ${ }^{35}$. On rapporte que l'imam Ibn Hanbal (m. 241/855) aurait déclaré que «dans l'ensemble des traditions relâchées, il n'y a pas plus faibles (ad 'af) que celles d'al-Bașrī et d'Ibn Abī Rabāh, [car] ils en recevaient de tout le monde ${ }^{36}$. " L'intransigeant critique Yahyā l-Qațạān (m. 198/813) avait déjà formulé un avis similaire, qui pourrait être vraisemblablement à l'origine de celui de son disciple Ibn Hanbal, dans lequel il considérait les marāsīl de Muḡāhid b. Ğabr (m. 103/721-2) de beaucoup supérieurs (bi-katîir) à ceux d'Ibn Abī Rabāḥ, qui transmettait de tout (min kulli darb) sans distinction ${ }^{37}$. De plus, le disciple attitré d'Ibn Abī Rabāḥ ${ }^{38}$, l'éminent hăfiz mecquois Ibn Ğurayğ (m. 150/767) (19 $^{39}$ avait interrompu sa transmission de celui-ci, dans les dernières années de sa vie, mais sans justifier cette interruption par la raison habituelle liée au radotage sénile et à la défaillance de la mémoire (ihbtilatt) due généralement au vieillissement ${ }^{40}$. Si l'on en vient au tadlīs, on voit qu'Ibn Abī Rabāḥ était

${ }^{34}$ Ibn Hanbal le considère avec al-Bașrī comme le plus prolixe d'entre tous les Suivants en matière de consultation juridique ( futyā), cf. Ibn al-Ṣalāh, Muqaddima, p. 517.

35 Selon un témoignage que l'on rapporte à Muhammad b. Idrīs al-Šāfíì (m. 204/820), cf. Iṣfahānī, Hilyat, III, p. 311. Sur Ibn 'Abbās et sa science infuse voir l'article de Claude Gilliot, "Portrait "Mythique” d'Ibn 'Abbās", Arabica, XXXII (1985), p. 127-84.

36 Al-Dahabī, Siyar, V, p. 86; aussi id., Mĩzàn, III, p. 70. Littéralement : «Ils les tenaient [les traditions] de n'importe qui».

37 Cf. al-Dahabī, Mìzān, III, p. 70.

${ }^{38}$ Il fut probablement le premier maître d'Ibn Ğurayğ qui transmettait de lui beaucoup de hadiths qui représenteraient environ $40 \%$ des hadiths rapportés dans le Musannaf de 'Abd al-Razzāq (m. 211/827), selon H. Motzki, The Origins of Islamic Jurisprudence. Meccan Fiqh before the Classical Schools, Leiden, Brill, 2002, p. 77, 94.

39 D'après 'Abd Allāh, le fils cadet d'Ibn Hanbal, celui-ci disait que "Amr b. Dīnār (m. 126/744) et Ibn Gurayğ sont les plus sûrs [garants] en ce qui concerne les hadiths de 'Ațāà ", cf. Ibn Hanbal, Masā̄il al-Imām Ahmad b. Hanbal bi-riwāyat ibnihi Abū l-Fadl Șāliḥ, éd. Faḍl al-Raḥmān Dīn Muhammad, Delhi, al-Dār al-ilmiyya, 1408/1988, II, p. 443, \$1133. Selon Ibn al-Madīnī (m. 234/849), «Ibn Ğurayğ est le seul au monde à maîtriser la connaissance [des hadiths] d'Ibn Abī Rabāḥ", lam yakun fî l-ard a lamu bi-bn Abì Rabāḥ min Ibn Guray̆g, cf. al-Dahabī, al-'Ibar fì habar man ğabar, éd. Șalāh al-Dīn al-Munağğid (I), Fu’ād Sayyid (II), al-Kuwayt, 1960-1, I, p. 213.

${ }^{40}$ Cf. al-Dahabī, Mìzān, III, p. 70. En commentant cette décision, al-Dahabī précise qu'il ne s'agit pas à son égard d'un "abandon» définitif (tark) au sens technique strict où l'entendent les spécialistes tardifs de la critique des autorités, à savoir qu'il est déclaré rāwī matrū $k$, celui-là qui s'est avéré menteur et forgeur de hadiths. Car, poursuit al-Dahabī, Ibn Abī Rabāḥ reste malgré tout un rapporteur sûr $(\underline{t} a b t)$. On peut supposer que, sur certains points, le cas d'Ibn Abī Rabāh correspond à la deuxième catégorie dans le classement d'Ibn al-Ğawzī. Elle se caractérise par le manque de vigilance au plan de la transmission, d'où « [...] leur erreur qui se répandit et devint ignominie» : fa-katura bațảuhum wa-fahuša, cf. id. K. al-Mawd̄̄àat, I, p. 36. 
rarement mis en cause par les critiques. Exception faite de la valeur suspecte de ses marāsīl, l'ensemble de ses transmissions directes d'Ibn 'Abbās jouit plutôt d'une certaine authenticité consensuelle ${ }^{41}$. Afin de mettre en exergue l'importance des avis défavorables aux traditions relâchées de ces deux éminents Suivants, Ibn Abī Rabāh et al-Bașrī, il nous faudrait donner un aperçu des avis positifs des critiques sur les marāsil d'autres autorités en vue à cette époque. Rappelons à ce propos qu'Ibn Hanbal était loin d'étendre sa sentence à toutes les traditions relâchées, puisqu'il rendit un jugement moins sévère sur les marāsil de quelques figures insignes de cette génération qui n’étaient pas spécialement marquées par le zuhd. Il teanait, par exemple, en haute estime les traditions relâchées transmises par Ibn Sīrīn ${ }^{42}$, considérait également meilleures entre toutes celles rapportées par Sa īd b. al-Musayyib (m. 94 ou 96/713 ou 715), l'un des sept juristes renommés de Médine, et admettait, enfin, à titre de traditions convenables, celles transmises par le grand juriste attitré de Kūfa, Ibrāhīm al-Naha ī (m. 92 ou 95/710-11 ou 714) ${ }^{43}$.

Nous devons garder à l'esprit qu'en établissant entre ces deux types de Suivants de la première génération, une distinction quant à la qualité incertaine de leurs marāsìl, cette dernière sentence nous donne à entendre qu'il existe en arrière-plan une démarcation d'un tout autre ordre, au sein de laquelle prime, en quelque sorte, l'évaluation de la propension de ces personnages au renoncement $^{44}$. Eu égard à leurs transmissions abondantes aussi bien qu'à leurs décrets juridiques pléthoriques, plus besoin de démontrer que le renoncement que cultivaient ces deux hommes était assez étranger au scrupule religieux (wara) qui faisait s'abstenir d'autres renonçants à prendre exagérément part à la futyā et à la riwāy $a^{45}$. La cause relative que pourrait constituer le renoncement devrait justement avoir pour effet l'inverse de ce résultat, c'est-à-dire que le zuhd est censé dissuader les renonçants d'être prolixes en matière de futyā et de riwāya. La conduite scrupuleuse, qui est au cœur de la pratique du

${ }^{41}$ H. Motzki, The Origins, p. 111.

42 Ibn Hanbal, $K$. al-'Ilal, I, p. 351-52, \$ 664.

43 Al-Dahabī, Siyar, V, p. 86. Au sujet des propos d'Ibn Hanbal sur les marāsīl de Sa īi b. alMusayyib, cf. id., Siyar, IV, p. 222; id., Tadkira, I, p. 54; Ibn Kațīr, al-Bidāya wa-l-nihāya, éd. Aḥmad Abū Mulhịm et Fu’ād al-Sayyid, Beyrouth, Dār al-kutub al-ilmiyya, 1405/1985, IX, p. 105.

${ }^{44}$ Leur origine ethnique non arabe ne saurait entrer en ligne de compte pour ce qui nous intéresse ici. À moins de faire appel abusivement à des arguments d'ordre psychologique et psychanalytique qui pourraient être avancés partout ailleurs, mieux vaudrait nous en tenir au tracé historique de ces personnages que nous livrent les sources narratives. Mais à la lumière d'une approche critique instructive qui ne laisserait pas à l'ombre les signes révélateurs des visées subjectives des auteurs de ces sources.

45 Supra, note 34. 
zuhd sur soi-même, requiert sobriété et pondération en toutes choses y compris le savoir religieux, et plus particulièrement le hadith. Il convient de rappeler au passage que la quête exagérée du hadith était, en effet, considérée comme un vice pour l'ascète sermonnaire 'Abd Allāh al-'Umarī (m. 184/800), bien avant que Bišr al-Hāfī (m. 227/841-2) n’en fît son credo ascétique au grand dam des traditionnistes auxquels il ne voulait plus avoir affaire en matière de transmission.

Suite aux deux exemples d'al-Bașrī et d'Ibn Abī Rabāḥ, il nous faudrait attirer l'attention sur un point capital dans la discipline de la critique des autorités ('ilm al-riğāll). Relativement à l'irrégularité qui caractérise la transmission chez ces deux Suivants, les critiques sont d'avis unanime qu'elle ne s'est avérée que dans les isnāds, qui plus est d'une façon partielle, indépendamment des matns. En mettant l'accent sur la différence entre les deux principaux modes opératoires du $t a d l i s^{46}$, il semblerait que les critiques aient voulu délibérément contribuer à l'exclusion de nos deux grands Suivants du répertoire des transmetteurs des munkarāt ou manākīr (sing. munkar). De toutes les raisons, car elles sont nombreuses de par leur nature variée, celle qui se détermine comme un moyen stratégique dans l'édification d'une idéologie religieuse sunnite reste la plus plausible. Confrontés à une telle configuration qui mettrait en jeu le bien-fondé d'un système doctrinal en construction, les représentants de l'institution du hadith n'avaient d'autre choix que de se prononcer pour une position qui ne fût pas préjudiciable aux acquis doctrinaux du sunnisme. Parce qu'autrement, ils auraient jeté le discrédit sur la teneur même de la tradition pour cause d'incompatibilité avec les autres matns pourvus de chaînes de garants indubitables ${ }^{47}$. Il en résulterait un grave jugement qui ne sied pas au rang supérieur de la stature de tels Suivants. De cette manière, l'on a plus affaire qu'à une suspicion qui, si extrême soit-elle, ne saurait être rattachée à la pratique délibérée de la «forgerie» des matns. La preuve est ainsi faite qu'il ne faut pas traiter les deux Suivants sur un même pied d'égalité que 'Abd Allāh b. Burayda (m. 115/733) et Šahr b. Hawšab (m. 84 ou 98/713 ou 716), les deux forgeurs notoires de hadiths de cette même

${ }^{46}$ Le tadlīs ne se limite pas à ces deux modes opératoires. Abū 'Abd Allāh al-Hākim al-Nīsābūrī en énumère six modes différents, cf. id., Márifat, p. 103.

47 En comparant leurs transmissions avec celles, déjà en circulation, d'hommes reconnus uniment crédibles, on s'aperçoit, écrit Muslim, qu'elles la contredisent, ou à peine s'y accordent-elles, cf. id., Șahīh, I, p. 7. Le munkar peut tout autant porter sur l'isnäd d'une tradition et être confondu avec le hadìt dit isolé (šäd $\underline{d}$, munfarid). Cependant, on différencie les deux par la probité incontestable du rapporteur en question, cf. Ibn al-Șalāh, Muqaddima, p. 244-46. Ibn Katīir semble ne pas tenir compte de cette distinction, car il assimile le šäd $\underline{d}$ et le munkar, cf. $i d$., al-Bä it al-hatīt, p. 58. 
époque. Il n'en reste pas moins fondé que cette distinction, instaurée à leur décharge, est tributaire de leur notoriété religieuse, réelle ou supposée, puisqu'ils passent pour être les fondateurs du sunnisme primitif.

\section{Deuxième génération}

La seconde génération de Suivants $\left(t a \bar{b} b i^{\prime} \bar{u} l-t a \bar{b} b i^{\prime} i ̄ n\right)^{48}$, a connu également cette catégorie de personnages qui se sont brillamment illustrés dans le renoncement et la dévotion cultuelle, mais dont la transmission s'est révélée, au jugement de bon nombre de critiques sunnites, peu fiable. Ces Suivants ont fait montre d'une grande abnégation religieuse, et ont témoigné d'un comportement édifiant d'autant plus sincère et détaché qu'il leur a valu énormément de considération et d'estime révérencielles. Par la vertu et le noble caractère auxquels ils exhortaient les gens dans les discours et maximes sapientiales qui leur sont attribués, ces hommes de Dieu ont un véritable ascendant spirituel et moral tant sur leurs contemporains que sur les générations ultérieures de mystiques. L'image de piété et l'auréole de sainteté que le commun des musulmans sunnites ont dressées d'eux a fait office de critère incontournable dans l'évaluation de leur degré de crédibilité en matière de transmission, étant donné que, leur sincérité sauve, certains d'entre eux ne seront pas ravalés au rang de forgeurs de matns. En raison de leur manque de vigilance comme de la latitude dont il ont fait preuve, on leur reprochera seulement d'avoir été excessivement crédules à l'égard de leurs sources de transmission (ruwāt). C'est sous ce rapport que les critiques conviennent volontiers de leur bonne foi, celle-là même qu'ils tiennent en même temps pour la principale cause de leur laxisme dans l'exercice de la riwāya. Cela laisse à entendre que ce trait, pourtant positif, leur a été préjudiciable, puisqu'ils n'ont jamais eu d'intentions malveillantes. C'est justement ce que tient si bien à souligner Muslim b. al-Hağğăğ (m. 261/870) dans l'introduction à son œuvre majeure, Șaḥiḥ, lorsqu'il commente le propos célèbre - devenu adage dans la littérature de

48 On appelle aussi les Suivants de la seconde génération $a t b \bar{a}^{c} a l-t a \bar{b} b i ̄ i n n$, et ceux de la troisième génération $a t b \bar{a}$ al-atbä. Ce classement des Suivants par générations successives est adopté dans l'ensemble des sources islamiques. En général, la première génération s'achève avec la mort d'al-Hasan al-Bașrī et d'Ibn Sīrinn, morts la même année en 110/728, la seconde, qui commence approximativement à partir de cette date, s'achève vers 179-180/795-796, date de mort de plusieurs personnages-clés du sunnisme, tels que Mālik b. Anas, Hammād b. Zayd, morts en 179/795, Muslim al-Zinğ̄i (m. 180/796). La troisième génération, quant à elle, s'étend jusqu'à la fin de la première moitié du troisième siècle de l'hégire, incluant du coup Ibn Hanbal (m. 241/855) et un bon nombre de juristes traditionnistes. 
'ilm al-riğăl - de l'un des premiers maîtres en la matière, le hăfiz Yahyā l-Qaț̣ān (m. 198/813). Ce dernier, à propos de trois éminents ascètes, tous des Baṣriens et disciples d'al-Bașrī de surcroît: Mālik b. Dīnār (m. 131/749), le compagnon de celui-ci Muhammad b. Wâsii (m. 123/740 ou 127/744) et Hassān b. Abī Sinān ${ }^{49}$, aurait déclaré ouvertement que: «l'on n’est confronté nulle part aux hommes pieux aussi menteurs qu'en matière de hadith ${ }^{50}$ [ils en rapportent de n'importe qui] ${ }^{51}{ }^{\prime}$. Et Muslim d'en conclure qu'al-Qațtān voulait dire par là que ces hommes pieux, șälihün "tenaient, certes, des propos mensongers, mais sans le faire intentionnellement ${ }^{52}$.» Or, plus d'un siècle plus tard, le hāafiz hanbalite Abū 'Abd Allāh b. Mandah (m. 395/1005), fera presque sienne la sentence de Yạ̣yā l-Qaț̣ān. Il aurait tenu un jugement similaire dans lequel il dénonçait la transmission des zuhbäd: «Si dans [la chaîne de transmission d'] un hadith tu t'aperçois de cette épithète: "un tel, l'ascète, nous a rapporté", alors lave-t'en les mains ${ }^{53}$.» Ces procès intentés aux zuhhäd ne concernent évidemment pas toutes les personnes de cette génération qui étaient enclines à l'ascèse, puisqu'il se trouvait parmi eux de nombreux rapporteurs largement appréciés pour leur mérite de garants comme pour leur qualité d'hommes renonçants.

À l'exclusion des ascètes les plus vénérés de cette époque, tels que Wuhayb b. al-Ward (m. 153/770) (54 $^{54}$ Mis'ar b. Kidām (m. 155/771) s5 $^{55}$ Ibrāhīm b.

${ }^{4}$ Cité par al-Dahabī dans la notice critique de Muhạmmad b. Wāsí, cf. id., Mĩzān, IV, p. 58, $\mathrm{n}^{\circ} 8285$. La date de mort de Hassān nous est inconnue, mais nous devons faire remarquer qu'avec Yahyā l-Qaț̣̄ān, il ne faut pas perdre de vue que c'est un Bașrien qui flétrit la qualité médiocre de la transmission d'autres Bașriens.

50 Cf. Muslim, Șahīh, introduction, I, p. 18.

51 La phrase entre crochets provient d'al-Dahabī, Mizān, IV, p. 58. Voir ce passage traduit par L. Massignon, Essai sur les origines du lexique technique de la mystique musulmane, Paris, J. Vrin, 1954, p. 123.

52 Muslim, Șaḥih, introduction, I, p. 18. Littéralement: "le mensonge coule sur leur langue»; voir aussi G.H.A. Juynboll, "Muslim’s introduction to his Șaḩīh», p. 281; Aḥmad Amīn, Fağr al-islàm, 5e éd., Le Caire, Mațba at lağnat al-ta’lif, 1364/1945 (?), p. 212; aussi L. Massignon, Essai, ibid.

53 Cf. Ibn Rağab, Šarḥ 'Ilal al-Tirmid̄ī, éd. Kamāl 'Alī l-Ğamal, al-Manșūra, Dār al-kalima, 1418/1998, p. 469.

54 Ibn Ma īn et al-Nasāì le tiennent pour un rapporteur digne de confiance (tiqa), cf. Ibn Hağar, Tahdīb, XI, p. 170, n 292.

55 L'un des grands maîtres traditionnistes, des plus respectables en 'Irāk, Wakī' b. al-Ğarrāh (m. 197/812-813) aimait à attester, dit-on, que «le doute de Miśá équivaut à la certitude des autres garants" (̌́akk Mis'ar ka-yaqin ġayrihi). Ibn Hanbal le considère l'égal de Šu ba b. al-Hağğăğg en termes de crédibilité, voir al-Dahabī, Siyar, VII, p. 164, n 55. 
Adham (m. 162/778) ${ }^{56}$ et Fuḍayl b. 'Iyāḍ (m. 187/803) ${ }^{57}$ pour n'en citer que les plus connus, dont la crédibilité est quasi certaine au jugement de la majorité des traditionnistes, il faut reconnaître que dans la somme impressionnante de dévots et d'ascètes très répandus au deuxième siècle de l'hégire peu ont été taxés, à un degré d'approbation conséquent, de garants menteurs (kad $\underline{d} \bar{a} b \bar{u} n$ ), de transmetteurs délaissés (matrükün) et encore moins de forgeurs de hadith (wadd $\bar{a}^{-} \bar{u} n$ ). Toutefois, c'est bien au cours de cette période que nous les verrons apparaître, comme catégorie distincte, dans le répertoire des garants susceptibles de forger des traditions. Alors qu'ils rejoignent d'un côté la série de garants forgeurs dont les motivations sont d'ordre politique ou dogmatique, de l'autre ils ne sont pas avalisés comme innovateurs (mubtadi' $a$, sing. mubtadi) au sens fort du terme où l'entendait les hérésiarques à l'adresse des hérétiques (zanādiqa, sing. zindīq) aux visées schismatiques. À preuve les hommes versés dans la science du hadith (al-muštagìiūn bi-l-ḩadit) seront mis en garde contre eux, mais sans pour autant occulter leurs qualités ascétiques que l'on presserait parfois de mettre en valeur en premier $^{58}$. En effet, de tels qualificatifs sont indignes d'un rapporteur (rāwi) à plus forte raison de celui qui est doublé d'ascète. Ces qualificatifs trouvent leurs places au bas de l'échelle hiérarchique des degrés d'évaluation à laquelle se réfèrent les critiques exercés dans la science de l'improbation et de l'approbation (al-ğarh wa-l-ta'dīl $)^{59}$. Il va sans dire qu’à partir du moment où la dévotion et la piété sont entraînées par l'observance de l'abstention scrupuleuse (wara) et de la conduite ascétique, elles deviennent des éléments majeurs dans la constitution du fondement de la sincérité requise pour toute activité de transmission des traditions prophétiques. En un mot, mesurer le fond de cette sincérité dont les critiques sont indubitablement convaincus s'avère insuffisant, eu égard aux divers degrés d'évaluation qui tiennent compte des défaillances humaines, telles l'illusion (wahm), l'erreur ( $\dot{g} a l a t$ ) l'omission (nisyān) et l'inattention (sahw) auxquelles ladite sincérité est spé-

56 Ibn Abī Hātim, Ğarh, II, p. 87, n 209 et Ibn Hağar, Tahdīb, I, p. 102-3 nº 176, en faveur de sa crédibilité citent les témoignages d'Ibn Ma īn, d'Ibn Numayr Muhammad b. 'Abd Allāh (m. 234/848), d'Aḥmad b. 'Abd Allāh b. Șālị̣ al-'Iğlī (m. 261/869), d'Ibn Hibbān al-Bustī (m. 354/965); voir aussi al-Dahabī, Siyar, VII, p. 388, nº 142.

${ }^{57}$ D’illustres imams, tels Ibn al-Mubārak, Yahyā b. Sa īd al-Qațtān, al-Šāfíī ont transmis de lui des traditions, cf. al-Dahabī, Siyar, VIII, p. 421, n 114. Voir aussi id., Tadkira, I, p. 246, nº 232; id., Mìzān, III, p. 361, n 6768; Ibn Rağab, Ğämi', I, p. 278-86.

${ }^{58}$ Ce procédé est largement usité dans les milieux mystiques, comme en fait état, par exemple, aussi bien Abū 'Abd al-Raḥmān al-Sulamī, dans ses Ṭabaqāt al-ṣūfyya, éd. Nūr al-Dīn Šarība, Le Caire, Dār al-kitāb al-'arabī, 1953 qu’al-Iṣfahānī dans sa Hilyat al-awliyà̃.

59 Ibn Hağar, Lisān, I, p. 8. 
cialement perméable ${ }^{60}$. À la différence de la transmission chez les Suivants enclins à l'ascèse, chez les dévots et des renonçants de la seconde génération la transmission se verra surveillée de près par les soins d'une critique vigilante en voie d'organisation. Bien que la déférence et la vénération restent encore de mise, voire quelquefois de rigueur à l'égard des plus influents parmi ces derniers, elles ne semblent plus beaucoup affecter l'évaluation des experts de la critique, du moins pas dans les mêmes proportions que naguère. En regard des faveurs autrefois concédées aux Suivants de la première génération, il ne fait plus de doute que le temps est à présent à une attitude moins laxiste, voire impartiale, de plus en plus renforcée en dépit de la considération que l'on ne manquerait pas d'éprouver pour leur piété si elle s'était avérée sincère.

Sur le plan de la critique, force est de constater qu'il y a eu avènement d'une conscience religieuse qui se veut rationnellement plus experte par rapport à son niveau de tâtonnement sous les traditionnistes de la génération antérieure. La codification de l'art de la critique, qui va de pair avec la systématisation de l'ensemble des sciences du hadith, ne laissera pas de repenser l'exemplarité ascétique pour juger de sa valeur à la lumière des règles de la transmission. Autrement dit, le zuhd n'est plus seul habilité à porter un jugement sur lui-même, dès lors que ceux qui s'en réclament se permettent de s'investir activement dans la propagande sunnite en usant de la tradition prophétique. Ainsi, comme nous l'avons signalé au départ, ici non plus il n'y aura pas lieu de voir une espèce d'intrusion des acteurs d'un groupe dans celui des autres, étant donné qu'il s'agit d'un seul et même groupe, qui, en évoluant dans des conditions différentes, se voit contraint, par l'effet de celles-ci, d'embrasser tantôt telle cause tantôt telle autre. Et pour l'exprimer d'une façon imagée, nous dirions qu'il s'agit, au lieu d'une scission d'un corps, de deux rameaux d'un unique tronc politico-religieux. Suite à cette conscience critique, on voit s'opérer un discernement, en conséquence duquel l'articulation entre zuhd et riwäya ne doit plus se faire aux dépens de cette dernière: l'ascèse, dont la parole est autrefois caution de la vérité, est décrétée insuffisante pour garantir seule la bonne qualité de la tradition. Toutefois, même lorsqu' elle est poussée à l'extrême de son exercice, cette conscience critique ne récuse pas catégoriquement toute forme de rapport entre ces deux tendances. En réalité, elle admet volontiers, comme éventualité à prendre en compte, que si les zuhhäd contreviennent aux règles de la riwāya c'est généralement par inadvertance, à moins qu'ils ne le fassent par excès de renoncement même, sans la moindre once de volonté de nuire sciemment au sunnisme dont ils servent le dessein. Dans un cas comme dans l'autre, une

${ }^{60}$ Ibn Abī Hātim, Ğarh, I, p. 10. 
marge de tolérance variable est laissée à la contribution ascétique contre laquelle le verdict ne tombe qu'à la suite d'un examen profond. C'est pourquoi, dans certaines chaînes de garants, on peut aisément reconnaître des figures insignes de cette génération contribuant à la transmission de hadiths dont la teneur est décrétée solennellement mensongère. Nonobstant le caractère de l'approche, un peu sélectif sur les bords dirions-nous, la critique tend à solliciter plusieurs paramètres pour faire toute la lumière critique nécessaire sur tel ou tel rāwi.

Évaluer convenablement le tort d'un rapporteur dont le renoncement et la pratique dévotionnelle sont reconnus aussi bien par le commun des musulmans que par l'élite des experts de la critique des ruwāt s'annonce une tâche des plus ardues. Afin de la mener à son terme, il va falloir être en mesure de faire un tri minutieux dans un fouillis de témoignages désordonnés et contradictoires, mais soigneusement et religieusement collectés, puis décider par la suite, de la bonne foi d'un garant dont on a éprouvé la crédibilité, de telle sorte à imputer le mensonge à celui ou ceux dont il aurait reçu la tradition. Et d'ailleurs les exemples qui vont dans ce sens sont légion, les sources narratives en abondent à des fins diverses difficilement imputables à une idéologie politique ou à une propagande religieuse données. Pour mieux illustrer cette approche critique dans laquelle la vénération ne fait plus tout à fait ombrage à la lucidité du jugement, bornons-nous en premier lieu à un personnage-clé, haut en couleur, dans les deux registres à la fois, ascèse et tradition, avant de passer en revue ceux qui, au contraire, étaient plus marqués par l'ascétisme que par le traditionnisme.

L'exemple du docte et ascète Huurāsānien, le mawlā 'Abd Allāh b. al-Mubārak (118/736-180/796), qui fut un traditionniste élevé au rang de ḩăfiz, et consacré imam de la communautét ${ }^{\text {, }}$, est très significatif. La prosopographie sunnite dresse de ce clerc religieux le portrait d'une autorité moraliste indéniable, mais aussi la stature d'un garant de hadiths digne de foi $(\underline{t} i q a)^{62}$. Elle le tient souvent pour un transmetteur probant $(h u \breve{g g} \breve{g} a)^{63}$, et se le présente aussi comme un maître traditionniste auquel le sunnisme doit en particulier de nombreux hadiths anciens, qu'il avait consignés en grande partie dans son

${ }^{61}$ Il aurait transmis une quantité impressionnante de hadiths, estimée à plus de vingt mille, cf. al-Hațīb al-Bagdādī, Ta’ rīh Bağdād, établi par Muhammad Sa īd al-'Irāqī, Le Caire, Maktabat al-Ḩānğĩ, 1349/1931, réimp. Beyrouth, Dār al-kitāb al-'arabī, 1970-1980, X, p. 163; al-Dahabī, Tadkira, I, p. 276; id., al-'Ibar, I, p. 280-1; Ibn Hağar, Tahdīib, V, p. 385.

${ }^{62}$ Ibn Abī Hātim, Garḥ, V, p. 181 ; al-Ḍahabī, Siyar, VIII, p. 388; Ibn Hağar, Tahdīib, V, p. 386.

${ }^{63}$ Al-Dahabī, Siyar, VIII, p. 380; Ibn Hağar, Tahdīb, V, p. 386. 
célèbre traité d'ascèse (Kitāb al-Zuhd $)^{64}$. Outre les nombreuses maximes à caractère ascétique qu'on lui reconnaît, on lui attribue l'une des sentences les plus appréciées des traditionnistes, relatée quasiment dans tous les ouvrages et manuels de hadith, dans laquelle il se fait le chantre de la chaîne de garants: "L'isnād, aurait-il dit, fait partie intégrante de la religion. N'était-ce l'isnād n'importe qui dirait n'importe quoi ${ }^{65} \%$. Ses témoignages relatifs à la qualité des transmissions des garants sont pris en compte dans de sérieuses évaluations de jugement effectuées par d'illustres spécialistes en l'art de l'improbation et de l'approbation (al-ğarh wa-l-tádìl) ${ }^{66}$. Et l'on consent bien volontiers à le considérer comme garant et critique à la fois ${ }^{67}$, dans la mesure où il fut l'un des premiers traditionnistes marquants dont nombre d'avis critiques sur ses contemporains ont été consignés dans de remarquables ouvrages de science de l'évaluation des autorités ${ }^{68}$.

Paradoxalement, aux yeux de certains critiques, réputés pour leur intransigeance dans l'examen des garants, Ibn al-Mubārak n'en reste pas moins un transmetteur peu soucieux de l'intégrité de ses sources. C'est pourquoi quelques impénitents d'entre eux ne s'étaient pas fait faute de lui faire grief d'avoir eu pour garants, malgré quelques sources de bonne foi (tiqāt) indéniables, des hommes de mauvaise foi. "Il fut, dit-on, un homme de bonne foi, sincère quant à ce qu'il rapporte, sauf qu'il rapportait [les hadiths] de n'importe qui ${ }^{69}$.» Le häfiz Yahyā b. Maīn (m. 233/848), dont Ibn Hanbal, son condisciple,

${ }^{64}$ Id., Kitāb al-Zuhd, éd. Habīb al-Raḥmān al-A'ẓamī, Haydarābād, 1386 h., réimp. Beyrouth, Dār al-kutub al-ilmiyya, s.d. Son Kitāb al-Raqä̉iq, d'après la recension de Nu'aym b. Hammād y est incorporé (p. 1-132). D’un point de vue chronologique, contrairement à ce qu'écrit D. Gril, «Les débuts», p. 31, Ibn al-Mubārak est le second auteur d'un traité de zuhd, car il aurait été, en toute vraisemblance, devancé par le traditionniste Abū l-Ṣalt Zāìida b. Qudāma l- Taqafī (m. 160/776).

${ }_{65}$ À titre d'exemple, voir Muslim, Șaḩĭh, I, p. 15; al-Hākim, Márifat 'ulūm, p. 6; Ibn al-Ṣalāh, Muqaddima, p. 437; Ibn Rağab, Šarh 'ilal, p. 94.

${ }^{6} 6$ Voir, par exemple, plus loin ses avis critiques sur 'Abbād b. Katīir, ou sur Šarīk b. 'Abd Allāh al-Naha'ī (m. 177/793), cf. al-Dahabī, al-'Ibar, I, p. 270, et sur d'autres personnages, passim.

${ }^{67}$ Al-Bulqīnī, Mahāsin al-iștilāh, in Ibn al-Ṣalāḥ, Muqaddima, p. 481. Il y signale une autre confusion à son actif, et non des moindres dirions-nous, étant donné le personnage: il aurait inséré le nom de Sufyān al-Tawrī dans un isnād auquel ce dernier est complètement étranger, ce qui traduit une ziyāda wa-wahm, cf. Ibn al-Ṣalāh, Muqaddima, p. 480.

${ }^{68}$ Voir plusieurs de ses témoignages dans l'introduction de Muslim à son Ṣahīh, I, p. 17sq. Il figure parmi les traditionnistes de la deuxième génération dont le savoir inclut la critique verbale des autorités, au même titre qu'Ibn 'Uyayna (m. 198/813), Wakī' b. al-Ğarrāh. Voir le développement de Scott C. Lucas, Constructive Critics, Hadith Literature, and the Articulation of Sunni Islam. The Legacy of the Generation of Ibn Sa'd, Ibn Ma'in, and Ibn Hanbal, Leiden, Brill, 2004, p. 147-48.

${ }^{69}$ Littéralement: "Il tient [ses traditions] de qui vient et qui s'en va», cf. Muslim, Ṣahīh., I, p. 19; A. Amīn, Fă̆r al-islàm, p. 212. 
estimait beaucoup la connaissance en matière de critique des riğga l, préférait ne pas accoler le titre de häfiz au nom d'Ibn al-Mubārak. Sans aucun doute qu'il estimait celui-ci loin d'acquérir toutes les connaissances nécessaires pour prétendre à un tel prestigieux titre, et qu'il le jugeait, par conséquent, en deçà du niveau de crédibilité requis. En donnant son avis critique sur la qualité des transmissions de ce dernier, Ibn Ma în s'en était tenu à l'épithète de Savant en religion (kàna 'älim), auquel il adjoignit, par commodité, la formule d'usage "garant dont les hadiths sont sains (saḥịh al-ḥadît $)^{70}$ " sans plus de précision. Al-Buhārī (m. 256/870), tout comme Abū l-Ḥasan al-Dāraquṭnī (m. 385/995) après lui, ont également attiré l'attention sur ses nombreuses erreurs de transmission, dont voici celle souvent citée comme exemple à son encontre: en entremêlant deux hadiths de sources différentes, Ibn al-Mubārak aurait inséré le nom du juge (qāể) syrien, Abū Idrīs al-Hūuānī (m. 80/699), dans une chaîne où celui-ci n'aurait jamais dû être. Preuve irréfutable qui vient renforcer la décision antérieure d'Ibn Ma'in, puisqu'une confusion de cette taille est indigne d'un garant du rang de ḩuğğa. Plus tard, et en dépit de toute l'admiration qu'il lui témoignait dans ses écrits, le hanbalite Taqī l-Dīn b. Taymiyya (m. 728/1328), fera observer que le traité d'Ibn al-Mubārak, Kitāb al-Zuhd, renferme des hadiths de très faible qualité $(w \bar{a} h i y a)^{71}$.

$\mathrm{Au}$ terme de ces critiques contradictoires, on voit qu'un personnage religieux de cette envergure, dont la piété, la dévotion cultuelle et le vaste savoir religieux sont relayés par une notoriété à l'échelle communautaire, continuait encore à avoir un puissant ascendant dans le milieu traditionniste auquel il avait appartenu. Néanmoins, l'amorce de la science de la critique des garants était une donnée historique de poids qui avait profondément marqué ce laps de temps étalé sur le demi-siècle allant de l'époque d'Ibn al-Mubārak à celle d'Ibn Ma īn (de 796 à 848). Il ne fait aucun doute que cette période, quoique relativement courte, était suffisamment déterminante pour n'avoir pas épargné à l'un des plus actifs acteurs de la propagande traditionniste de faire les frais de la critique. Le ton de celle-ci reste certes modéré, mais l'esprit rationnel qui la fonde n'en est pas moins conscient de la distinction formelle qui s'impose désormais entre sincérité mystique et fiabilité en transmission. Plus précisément, la seconde ne découle plus systématiquement de la première. Par voie de conséquence, même en sa triple qualité d'imam adulé, de combattant dans la voie de Dieu dans des ribāț et d'ascète respecté que personne

70 Cf. al-Bag̀dādī, Tả rìh, X, p. 164; Ibn Hağar, Tahdīib, V, p. 385.

${ }^{71}$ Cf. Hāğğği Halīfa, Kašf al-zunūn 'an asāmī l-kutub wa-l-funūn, éd. S. Yaltkaya et Kilisli Rifat Bilge, Istanbul, 1941-1943, réimp., Maktabat al-Mutannā, Baġdād, s.d., réimp., Beyrouth, Dār al-kutub al-ilmiyya, II, p. 1423, cf. aussi l'excellente introduction de l'éditeur, Habīb al-Rahịmān al-A'ẓamī, in K. al-Zuhd, p. 16. 
ne mettait en cause, la sincérité d'Ibn al-Mubārak ne pouvait suffire à elle seule à l'ériger en huğğga au sein de la science du hadith. Mais alors, si telle était la situation pour un rapporteur de sa stature, serait-ce nécessairement le même traitement que la critique réservait aux transmetteurs ascètes et dévots étrangers au milieu traditionniste? Pour nous en rendre compte, il nous faudrait passer en revue les grandes figures emblématiques de l'ascèse à l'époque d'Ibn al-Mubārak.

Prenons le cas d'un des disciples d'al-Hasan al-Bașrī, le Baṣrien 'Abd al-Wāhid b. Zayd (m. après 150/766 ?) ${ }^{72}$ qui fut un célèbre sermonnaire $\left(w \bar{a}^{\prime} i z\right)$ à la tête d'un courant mystique très répandu dans tout l'Irak. Tout comme son maître avant lui, ce dernier prônait une conduite morale exemplaire qui repose foncièrement sur la retraite spirituelle ('uzla) et l'esseulement $(w a h d d)^{73}$. Il fonda le cloître (ribāț) de 'Abbādān, lieu légendaire de rassemblement où nombre d'ascètes de diverses régions venaient se regrouper en masse en vue d'exercices spirituels ${ }^{74}$. L'état de pessimisme intérieur, déjà amorcé par son maître al-Bașri $\overline{1}^{-75}$, avait atteint avec lui à un degré d'observance tel que les historiographes se voyaient amenés à proposer cette analogie pour en souligner l'étendue: «Si sa tristesse d'âme (battr) venait à être distribuée sur tous les habitants de la cité de Bașra, elle les embrasserait tous ${ }^{76}$.» Il était considéré au nombre des intimes de Dieu (awliy $\bar{a}^{-}$) dont les prières sont

72 Sa date de mort reste incertaine. Al-Dahabī la situe après l'an 150 de l'hégire, mais met en doute qu'elle puisse aller jusqu'à 177/793. Car alors, pense al-Dahabī ce ne serait qu'une confusion avec la date de mort du traditionniste 'Abd al-Wāhid b. Ziyād, cf. id. Siyar, VII, p. 180. C'est aussi la précision qu'apporte J. van Ess dans Theologie und Gesellschaft in 2. und 3. Jahrhundert Hidschra. Eine Geschichte des religiösen Denkens im frühen Islam, Berlin, New York, Walter de Gruyter, 1990-1997, II, p. 97. Cependant, al-Dahabī le cite parmi les personnages morts à cette date dans son al-'Ibar, I, p. 280.

73 Al-Dahabī, Siyar, VII, p. 179; L. Massignon, Essai, p. 214.

${ }^{74}$ L. Massignon, ibid., aussi Molé Marijan, Les mystiques musulmans, Paris, PUF, 1965, p. 39.

75 Sur cet état de tristesse intense ( huzn) qui caractérise al-Bașrī, voir Ibn Hanbal, K. al-Zuhd, p. 441-88: p. $441-3: \$ 1464,1466,1467,1468,1472,1473$, p. $447: \$ 1493,1494$, p. 453 : $\$ 1524$, p. $471: \$ 1616,1617$, p. $473: \$ 1627$, p. $476: \$ 1641$, p. $480: \$ 1662$.

${ }^{76}$ Cf. al-Dahabī, Siyar, VII, p. 179. Certes, le mot bațt exprime en général le huzn, hamm et gamm à la fois. Mais, plus précisément, il dénote selon Ibn Manẓūr, un sentiment de tristesse d'une intensité (šiddat al-ḥuzn) telle que celui qui en souffre se presse de le partager avec quelque ami ou confident pour épancher son cœur, cf. Lisān al-'Arab, Beyrouth, Dār Șādir, $1956 / 1375$, II, p. 114. Nous avons tenu à faire ce rappel lexicographique pour attirer l'attention sur cette phrase erronée dans la notice biographique que consacre al-Dahabì à 'Abd al-Wāhid b. Zayd, dans Mizān, II, p. 672-3, n 5288, p. 673. Il semble plutôt qu'elle soit due à l'éditeur critique 'Alī Muhammad al-Biğāwī qui y déchiffrait le mot ḥadīt au lieu de bațt, d'où le sens général qui en est altéré, d'autant plus que 'Abd al-Wāhid b. Zayd n'avait pas rapporté abondamment de hadiths. 
exaucées $^{77}$. En tant que muhaddit, c'est souvent à de hauts personnages ascétiques que remontent ses transmissions, au premier rang desquels on retrouve naturellement son maître al-Bașrī et l'imam de La Mecque, Ibn Abī Rabāh, les deux maîtres dont nous avons démontré que leurs traditions relâchées étaient taxées de faibles ${ }^{78}$. À la différence d'Ibn al-Mubārak qui était lavé de tout soupçon de tadliss, 'Abd al-Wāhid b. Zayd, quant à lui, n'était pas seulement suspecté d'avoir eu recours au tadlìs du second degré, c'est-à-dire la tromperie dans laquelle l'irrégularité survient sur le plan de l'isnād, mais on lui reprochait surtout d'avoir sciemment inventé des matns qu'il faisait ensuite remonter au Prophète, à travers des chaînes de transmission prêtes à l'emploi. Sur le plan technique, en nous référant au lexique en usage dans le domaine de la critique, ce dont on l'accusait c'est d'avoir intentionnellement pratiqué "le vol des chaînes de garants» (sariqat al-isnād) $)^{79}$, procédé par lequel le forgeur prête des propos pseudo prophétiques, qui sont en réalité de sa propre fabrication, à des autorités religieuses estimées, formant déjà une chaîne de garants valide; et cela bien évidemment dans l'intention répréhensible de faire passer ses propres dires pour d'authentiques traditions prophétiques. Les charges de tricherie qui pèsent contre lui étaient d'autant plus sévères qu'il était lui-même moins investi dans la sphère du hadith. Et l'on ne s'étonnera pas davantage de relever que les critiques se sont prononcés unanimement pour sa disqualification définitive du nombre des transmetteurs crédibles. C'est pourquoi Ibn Hibbān (m. 354/965) lui a fait grief de s'être laissé tenter par ce subterfuge, qui plus est aux dépens de la réputation de son mầtre al-Bașri1 ${ }^{-80}$. De là la sentence formulée par les critiques postérieurs, parmi lesquels on citera Ibn Ma īn ${ }^{81}$, al-Buhāriri ${ }^{82}$, Abū 'Abd al-Raḥmān al-Nasāà (m. $303 / 915)^{83}$, et par de nombreux autres qui se sont joints à leur opinion ${ }^{84}$. En vertu de cette condamnation, toutes les transmissions de 'Abd al-Wāhid b.

77 Al-Dahabī, Mizän, II, p. 673.

${ }_{78}$ Al-Dahabī, Siyar, VII, p. 178; Ibn al-Imād, Šadarät, I, p. 287.

79 Voir sur le procédé de sariqat al-isnād, l'ouvrage de 'Umar b. Hasan Falāta, al-Wad' fì l-hadît, Beyrouth, Damas, Maktabat al-Gazālī, 1401/1981, I, p. 39-41.

80 Voir Burhān al-Dīn al-Halabī, al-Kašf al-hatīit 'amman rumiya bi-wad' al-hadìt, éd. Subhị 1-Sāmarrāīì, Bagdad, Maṭba at al-Ānī («Ihyāà al-turāt al-islāmī»), 1984, p. 277-8, nº 468: kadaba 'an al-Hasan wa-wada' a 'alayhi.

${ }^{81}$ Ibn Muhriz, Márifat al-riğăl 'an Yahyā b. Måin bi-riwāyat Ibn Muhriz, éd. Muhammad Muțī al-Hāfiz et Gazwat Badīr, Dār al-ma ārif, Damas, 1405/1985, II, p. 169, nº 542 : «celui-ci est faible ( $\left.h \bar{a} \underline{d} \bar{a} d a^{\prime} i \bar{f}\right)$ ».

${ }^{82}$ Cf. al-Buhārī, Kitāb al-Tả rīh al-kabìr, Beyrouth, Dār al-kutub al-ilmiyya, 1986, VI (III²), p. 62, n' 1713: [..] tarakūhu, «il a été abandonné».

${ }^{83}$ Al-Nasāìi, Kitāb al-Du'afä wa-l-matrūkìn, éd. K. Yūsuf al-Hūt \& Būrān al-Ḍannāwī, Beyrouth, Mu’assasat al-kutub al-taqāfiyya, 1985/1405, p. 162, nº 391: [.. ] matrük al-hadìt.

${ }^{84}$ Cf. al-Dahabī, Mizzän, II, p. 672-3, n 5288; id., al-'Tbar, I, p. 280. 
Zayd sont promises à l'abandon total, sous peine, pour quiconque s'aventurerait à les faire circuler, de passer lui aussi pour menteur. Ainsi, la place qu'on lui assigne se décline dans le rang de "garants dont le hadith est rejeté» (matrūk al-hadìt).

En effet, il s'agit bel et bien de l'autre versant de la critique qui s'intéresse, après examen minutieux de leurs isnāds, à la teneur des traditions. Il a pour objet de fixer un seuil, déterminé par l'incongruité du message du matn au regard de l'esprit du sunnisme, seuil au-delà duquel ces traditions doivent être tenues pour «suspectes et inconnues" (manäkîr al-ḥadit), au sens où l'on est persuadé qu'elles sont purement du cru du rapporteur lui-même. Comme exemple que les critiques manquaient rarement de citer pour témoigner de l'abus de mensonge reproché à 'Abd al-Wāḥid b. Zayd, bornons-nous à ce hadith dont ils étaient convaincus qu'il lui avait été inspiré par le modèle ascétique auquel il s'astreignait et qu'il prêchait pour ses fidèles: «Un corps nourri d'[aliments] illicites n'accède pas au Paradis ${ }^{85}$.» Et l'on doit se résoudre à admettre que l'enseignement dont ce hadith est porteur, est en contradiction complète avec ceux prêtés au Prophète et les interprétations admises des passages coraniques qui en traitent, dans lesquels le Paradis est promis en tant qu'ultime demeure pour tout croyant pêcheur.

Comme dévot d'origine bașrienne, nous ne devons pas perdre de vue l'un des plus influents dévots contemporains de 'Abd al-Wāhìid b. Zayd, 'Abbād b. Katîir (m. 150 ou 160/766 ou 777) ${ }^{86}$ qui vécut longtemps à La Mecque. Il n'était pas complètement étranger au milieu traditionniste, puisqu'on rapporte qu'il aurait été emprisonné sur ordre du deuxième calife 'abbāside, Abū Ğa far al-Manșūr (m. 158/775), avec deux autres imams éminents: Sufyān al-Tawrī (m. 161/778) et Ibn Ğurayg $\breve{g}^{87}$. Bien que rarement mentionné comme zähid par les historiographes traditionnistes et mystiques, son nom était fréquemment associé aux cercles des pieux et des dévots. Comme pour la plupart des rapporteurs de sa catégorie, caractérisée par la dévotion cultuelle, lui aussi, dans les hadiths qu'il transmettait, se référait exclusivement, à des personnages d'obédience ascético-mystique ${ }^{88}$. En sa qualité de transmetteur, en revanche, 'Abbād b. Katīi est mis à l'index par l'ensemble

${ }^{85}$ Ibid., II, p. 673: lā yadhulu l-̌̆anna ğasad ğuddiya bi-h̦arām.

${ }^{86}$ Al-Dahabī situe sa date de mort dans cette décennie, cf. id., Mĩzān, II, p. 371-75, p. 375, $\mathrm{n}^{\circ} 4164$.

${ }^{87}$ Abū Ğa far al-Ṭabarī, Tảrīh al-umam wa-l-mulūk, éd. Muh. Abū l-Faḍl Ibrāhīm, Le Caire, 1967, réimp., Beyrouth, Dār al-turāt, s.d., VIII, p. 58-9.

${ }^{88}$ Les plus marquants d'entre eux à cette époque sont: al-Hasan al-Bașrī, Mālik b. Dīnār (m. 131/749), Ayyūb al-Saḩtiyānī (m. 131/749), cf. Ibn Abī Hātim, Ğarḥ, VI, p. 84; al-Ḍahabī, Siyar, VII, p. 106. 
des critiques, à commencer par ses contemporains, y compris Ibn al-Mubārak dont nous avons vu qu'il relève jusqu'à un certain niveau de la même tendance ascétique que lui. Quoique ce dernier avoue le tenir en grande estime pour son rang d'homme de piété qui faisait preuve de détachement quant aux biens de ce monde, il se fit un devoir de conseiller vivement aux collecteurs des traditions qui venaient s'instruire auprès de lui de se tenir à distance de 'Abbād b. Katīir ${ }^{89}$. Il en va de même pour al- Tawrî̀ $^{-90}$ ainsi que pour le plus fin et intransigeant critique de cette époque en Irak, Šu'ba b. al-Hağğăğ (m. $160 / 776)^{91}$, qui s'accordaient tous deux à mettre les traditionnistes en garde contre lui. Par la suite, les critiques de la génération postérieure seront nombreux, à la faveur des témoignages de ces derniers, à réitérer le statut de suspect grave pour 'Abbād b. Kațīr, dont les hadiths doivent être frappés de nullité, et par là même être retirés des circuits de la transmission saine. Et voici qu'Ibn Ma īn, qui nous a souvent accoutumés à des sentences dépourvues du moindre ménagement, sans la moindre considération pour ses prouesses dévotionnelles, opte pour le rejet en bloc de toutes ses transmissions ${ }^{92}$. De son côté Ibn Hanbal, tout en reconnaissant avoir été très sensible à sa ferveur religieuse dont il ne conteste pas la sincérité, faisait remarquer que plusieurs traditions transmises par lui s'étaient révélées mensongères ${ }^{93}$. À leur tour, les critiques de la génération suivante qui se sont penchés sur le cas de 'Abbād b. Katîir ont abouti, après examen du contenu de ses traditions et de ses chaînes de garants au même résultat à l'issue duquel ils ont émis des avis négatifs qui ne souffrent aucune interprétation modérée: al-Buhārī, par exemple, confirme son rang de garant délaissés ${ }^{4}$, l'éminent hăfiz Abū Zura a l-Rāzī l-Kabīr (m. 264/878) conclut, quant à lui, qu'il ne faut plus transcrire les hadiths venant de lui ${ }^{95}$, enfin al-Nasāì leur donnera raison en réaffirmant que 'Abbād b. Katīir faisait partie de ceux dont les hadiths doivent être abandonnés ${ }^{96}$.

Les répertoires biographiques des personnages religieux font état d'un autre ascète de cet acabit, du nom d'Abū Bišr Sāliḥ al-Murrī (m. 173 ou 176/790

\footnotetext{
89 Muslim, Șaḥih, I, p. 17.

90 Al-Dahabī, Mìzān, II, p. 372; S.C. Lucas, Constructive, p. 142, note 93. Traditionists of Bașra", Le Muséon, 111 (1998), p. 187-226.

${ }_{92}$ Voir Burhān al-Dīn al-Halabī, al-Kašf al-ḥatīit, p. 222, n' 366.

93 Ibn Abī Hātim, Ğarh, VI, p. 84.

94 Al-Buhārī, K. al-Tà rì

95 Ibn Abī Hātim, Ğarh, VI, p. 85.

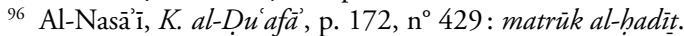

91 Muslim, Șahīh, I, p. 17. Au sujet des positions de Šu'ba b. al-Hağğāğ sur les transmetteurs bașriens, voir G.H.A. Juynboll, «Shu'ba b. al-Hajjajj (d. 160/776) and his Position among the 
ou 793 $)^{97}$ qui s'avère être aussi un Bașrien. Il fut un homme de notoriété publique qui jouissait d'une grande réputation de mystique sermonnaire, dont les prêches, écrit-on, donnaient lieu à des audiences prisées par le peuple. Quelquefois il est dépeint, dans certains de ces répertoires, sous les traits d'un conteur public (qāsss ) notoire ${ }^{98}$. On lui prête une conduite édifiante, qui était cependant marquée par deux grandes qualités qui lui étaient propres: une crainte excessive de Dieu dont était imprégnée sa récitation publique du Coran, et une invocation ( $\underline{d} i k r)$ permanente de Dieu par laquelle il s'exerçait à un continuel apostolat ${ }^{99}$. Objets de fortes affluences, ses sermons avaient un impact spirituel d'autant plus considérable qu'il n'aurait même pas épargné, dit-on, l'une des hautes statures du traditionnisme du moment, à savoir le juriste Sufyān al-Tawrī. Si l'on ajoute crédit au témoignage du disciple de celui-ci, le ḩäfiz Ibn Mahdī (m. 198/813), il semblerait qu'al-Tawrī aurait été profondément ému par les exhortations d'al-Murrīion. Dans sa pratique de l'ascèse, n'omettons pas de signaler qu'à l'instar de son contemporain 'Abd al-Wāḥid b. Zayd, al-Murrī avait renoué profondément avec l'état psychologique d'attrition intérieure qui caractérisait son maître al-Bașrī, qui se trouve également être la source de transmission principale à laquelle il faisait remonter bon nombre de traditions qu'il diffusait ${ }^{101}$. En dépit de toute la considération due à son rang incontesté d'ascète et de mystique sermonnaire, s'agissant de sa qualité de transmetteur de traditions, il en va tout autrement de sa valeur d'homme crédible. Effectivement, al-Murrī était déjà tenu en piètre estime par les critiques de sa génération, tel Hammād b. Salama (m. 167/783) qui le taxait de menteur, plus particulièrement au sujet d'un hadith dont il aurait été le principal instigateur ${ }^{102}$. Il ressort de l'ensemble des avis critiques sur la qualité de ses transmissions qu'al-Murrī s'inscrit au nombre des garants dont les hadiths, outre les chaînes de garants parfois fantaisistes, souffrent des tares ('ilal, sing. 'illa) intolérables au niveau de leurs matns. Il n'était peut-être pas aussi sévèrement malmené que son contemporain 'Abd al-Wāḥid b. Zayd,

97 Al-Buhārī, K. al-Tả rīh, IV (II²), p. 273, n 2782, le fait mourir en l'an 176/793; mais al-Ḍahabī, dans Mizān, II, p. 289, propose l'an 173/790. À ne pas confondre avec 'Abbād b. Katīir al-Ramlī dont la notice vient souvent après la sienne dans les recueils biographiques. Voir surtout al-Halabī, al-Kašf, p. 220-2.

98 Al-Dahabī, Siyar, VIII, p. 46.

99 Ibid., p. 47.

100 Ibn Sa'd, Tabaqāt, VII, p. 281.

101 Al-Dahabī, Siyar, VIII, p. 47

102 Muslim, Șahīh, I, p. 23 
mais al-Murrī n'en était pas moins décrié comme un notoire forgeur de manākìr dont les traditions, en fin de compte, doivent être rejetées ${ }^{103}$.

S'inscrit également dans cette veine de transmetteurs, l'ascète Manșūr b. 'Ammār al-Sulamī - très vraisemblablement d'origine bașrienne - (mort aux environs de 200/815) ${ }^{104}$, qui fut un sermonnaire de premier ordre, apprécié de tous aussi bien en Irak qu'en Syrie et en Égypte ${ }^{105}$. Contrairement aux personnages précédents qui en sont absents, celui-ci est recensé dans la prosopographie de la mystique sunnite. Dans ses Ṭabaqāt, Abū 'Abd al-Raḥmān al-Sulamī (m. 412/1021) ${ }^{106}$ le fait passer pour une figure sainte du soufisme ancien dont les sermons publics étaient d'une grande portée spirituelle ${ }^{107}$. De même dans sa Hilyat al-awliyă, le disciple de ce dernier, Abū Nu'aym al-Iṣfahānī (m. 430/1038) s'évertue à le présenter sous les traits d'un personnage mystique haut en couleurs ${ }^{108}$. Deux siècles plus tard, le grand poète mystique persan Farīd al-Dīn 'Aț̣āa (m. 628/1230) fait de même dans son célèbre traité hagiographique Tậdkirat al-awliy $\bar{a}^{-109}$. Néanmoins Manșūr b. 'Ammār n'était pas seulement adulé par les traditionnistes postérieurs de tendance mystique, mais il jouissait aussi, de son vivant, du soutien solide d'éminentes figures religieuses. Et pour nous en tenir au cas le plus significatif, rappelons le soutien moral et surtout matériel que lui procurait le traditionniste et maître légiste attitré d'Égypte (muftì l-diyār al-mișriyya), al-Layt b. Sa 'd al-Fahmī (m. 174/792). Ayant été très satisfait de ses prédications, nous dit-on, ce dernier l'aurait autorisé, à titre exceptionnel, à dispenser des sermons en public dans toute l'Égypte musulmane ${ }^{110}$.

L'on s'attendrait à ce qu'une si forte relation avec un transmetteur du rang d'al-Layt, qui était reconnu comme autorité probante ( $h u \breve{g g ̆ g} a)$ par l'ensemble

103 Al-Buhārī, K. al-Tảrīh, IV (II $\left.{ }^{2}\right)$, p. 273, munkar al-ḥadīt. La sentence d'Abū Dāwud al-Siğistānī (m. 275/889) reste la plus nettement expéditive: "ne pas transcrire son hadith", lā yuktabu ḩadītuhu, cf. al-Dahabī, Siyar, VIII, p. 47. Al-Nasāì le qualifie également de matrūk

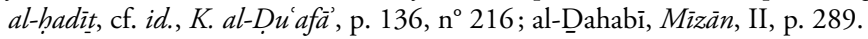

${ }_{104}$ N'ayant rien trouvé sur sa date de mort, al-Dahabì suggère à titre indicatif l'an 200 de l'hégire, cf. id., Siyar, IX, p. 98. D’ailleurs, toutes les autres références, consultées et citées cidessous n'ont rien indiqué au sujet de sa date de mort.

105 Al-Dahabī, Siyar, IX, p. 94.

106 Cf. al-Sulamī, Tabaqāt al-șüfyya, p. 130-36, n 17.

107 On trouve quelques-uns de ses apophtegmes regroupés à la fin de sa notice, cf. ibid., p. 134-6.

108 Al-Iṣfahānī, Hilyat, IX, p. 325-31, n 455.

109 'Ațțār, Le mémorial des saints, traduction de A. Pavet de Courteille, Editions du Seuil, 1976, p. 260-2.

110 Al-Bagdādī, Tảrīh, XIII, p. 72; Ibn 'Asākir, Tảrīh madīnat Dimašq, éd., Muhibb al-Dīn 'Umar al-'Amrawī, Beyrouth, Dār al-fikr, 1416/1995-1421/2001, LX, p. 332-33; Ibn Manzūr, Mubtașar Tảrīh Dimašq li-bn 'Asākir, Beyrouth, Dār al-fikr, 1404/1984-1408/1988, XXV, p. 259. 
des critiques du hadith, jouerait en faveur d'Ibn 'Ammār, du moins en matière de transmission. Or malgré ce solide lien bien établi entre les deux hommes, Ibn 'Ammār n'en était pas moins taxé de garant qui laisse à désirer ${ }^{11}$. La raison première en est encore la fragilité de ses isnäds, puisqu'ils se rattachent quasi exclusivement, comme pour ses prédécesseurs ascètes, à des maîtres versés dans l'ascèse, désertant ainsi les canaux officiels de garants traditionnistes confirmés. D'où une suite d'avis négatifs sans appel à son endroit, qui vont s'endurcissant. Ainsi, pour Abū Hātim al-Rāzì (m. 277/890) de la génération qui suit celle d'Ibn 'Ammār, celui-ci était perçu comme un garant dépourvu de compétence en la matière, somme toute un intrus frappé de faiblesse par son amateurisme ${ }^{112}$. Mais la critique, maîtrisant de plus en plus son appareil qu'elle voyait s'ordonner à mesure qu'il s'enrichissait, allait par voie de conséquence s'accentuer au siècle suivant contre lui. L'avis le plus avisé qui en témoigne est celui d'Ibn 'Adī l-Ğurğānī (m. 365/976), qui pense que ce sont en vérité toutes les transmissions d'Ibn 'Ammār qui doivent être considérées comme suspectes (munkarāt). Et Ibn 'Adī d'avancer plusieurs raisons à cette affirmation, dont la principale fait état de la pertinence de l'analyse qui met en parallèle le matn et l'isnād pour juger de leur cohérence par la réalité historique de leurs liens qui semblent désormais répondre à une grille de concordance entre la nature du message délivré par le matn, et l'identité religieuse et géographique des rapporteurs mentionnés dans l'isnäd. Cette raison tient à la frappante ressemblance de la teneur des traditions d'Ibn 'Ammār qui contraste étonnamment avec la dissemblance des autorités auxquelles il s'employait à les faire remonter par le biais de plusieurs chaînes de garants différentes ${ }^{113}$. Par une justification aussi bien formulée, il est clair qu'Ibn 'Adī est convaincu qu'Ibn 'Ammār s'était livré au "bricolage» des chaînes de garants (tarkīb al-asānid) dans l'intention de faire passer, sinon pour authentiques, du moins pour bonnes (ḩasana), des traditions à l'origine suspectes. Pour al-Dāraquṭnī, qui se range bien évidemment à l'opinion d'Ibn 'Adīi, il fut un garant de hadiths faible ${ }^{114}$.

Du reste, il y a une toute autre raison qu'il conviendrait de relier au déplorable sort d'Ibn 'Ammār en tant que rapporteur de hadiths et qui aurait déjà fait pencher l'opinion des traditionnistes en sa défaveur. Il s'agit d'une brève

111 Abū Ğa far al-'Uqaylī, Kitāb al-Ḍu afä̀ al-kabīr, éd. 'Abd al-Mu'țī Amīn Qal'ağī, Beyrouth, Dār al-kutub al-ilmiyya, 1404/1984, IV, p. 193: là yuqìmu l-ḥadīin; al-Dahabī, Siyar, IX, p. 94: lam yakun bi-l-mutadalli min al-ḥadìt.

112 Ibn Abī Hātim, Garḥ, VIII, p. 76, nº 777 : laysa bi-l-qawi.

113 Ibn 'Asākir, Ta’rīh, LX, p. 327. Ibn 'Adī fait remarquer aussi qu'il le tient pour tel, parce qu'il rapportait des traditions d'une quantité de garants peu connus ( $\dot{g} a y r$ mašhür), et surtout de 'Abd Allāh b. Lahī'a (m. 174/790) dont les hadiths ont été délaissés.

114 Al-Dahabī, Siyar, IX, p. 94. 
rencontre qui se serait très mal passée avec un personnage clé du traditionnisme, Ibn 'Uyayna (m. 198/813), juriste et chef de file des gens du hadith à La Mecque. On rapporte, en effet, qu'à l'issue d'une vive altercation entre les deux hommes, ce dernier, qui n'avait pas du tout apprécié les questions insistantes d'Ibn 'Ammār à propos de la nature du Coran, l'aurait violemment repoussé, puis traité de démon (šaytānn) en pointant, l'air courroucé, sa canne dans sa direction ${ }^{115}$. C'est vraisemblablement pour cette raison que son sympathisant, Abū Nu'aym, a préféré, dans sa Hilyat al-awliyàa', se passer de cette version en en proposant une autre, bien entendu retouchée, qui serait rapportée d'Ibn 'Ammār lui-même par l'intermédiaire de son fils Sulaym. Alors que la première version de la rencontre est clairement hostile à notre sermonnaire, dans celle-ci au contraire on s'efforce de nous dépeindre une entrevue en sa faveur. Il s'ensuit une rencontre qui se serait plutôt très bien déroulée entre les deux hommes, et qui a permis, par la même occasion, de souligner les grandes facultés persuasives du prédicateur que fut Ibn 'Ammār, dont les paroles apprêtées auraient si bien ému Ibn 'Uyayna qu'il en avait eu les larmes aux yeux ${ }^{116}$.

Il n'en va pas autrement pour plusieurs autres ascètes éminents de cette génération, qui sont en bonne partie irakiens, mais dont la majorité écrasante est d'origine bașrienne. Les traditionnistes, pour la plupart, évitent de s'en prendre à leur mode de vie ascétique de manière systématique. Mis à part les rares cas à caractère strictement personnel, qui nous ont été signalés par les historiographes au travers de notices biographiques diverses, les spécialistes en matière d'examen des garants semblent s'être fait le scrupule de ne pas se prononcer sur la véracité de ce que l'on rapporte de ces derniers, faisant preuve de complaisance pour ne pas dire d'indifférence à leur égard, du moment qu'il ne s'agissait que de leurs prouesses spirituelles ou de leurs réalisations mystiques. Ils se gardent bien de porter un jugement sur des témoignages enthousiastes que portaient à leur crédit de fidèles disciples acquis à leur cause. Mais se tenir à cette distance est néanmoins soumis à une double condition qui devient impérative à la faveur de la propagande sunnite de facture traditionniste. La première condition consiste à ce que ces individus ascètes ne cèdent plus à la tentation de l'immixtion dans le champ désormais réservé de la transmission de hadiths dans le but d'asseoir les fondements de

115 Al-'Uqaylī, K. al-Ḍu 'afä’, IV, p. 194; Ibn 'Asākir, Ta’rīb, LX, p. 335; al-Ḍahabī, Siyar, IX, p. 94; id., Mizānn, IV, p. 187. Ibn 'Uyayna ne l'aurait peut-être pas traité de satan, si l'assistance, en vue de calmer la dispute, n'était pas intervenue pour lui dire qu'après tout Ibn 'Ammār est un homme dévot et pieux. C'est dans ce contexte qu'il aurait fini par s'écrier spontanément : $m \bar{a}$ arāhu illā šaytānan, "à mon avis c'est plutôt un démon".

116 Al-Iṣfahānī, Hilyat, IX, p. 327. 
leurs valeurs mystiques aux frais d'une science religieuse sérieuse à laquelle s'identifie le hadith. Quant à la seconde condition, qui s'inscrit dans la perspective globale du sunnisme, elle a pour objet de contenir tout débordement d'ordre dogmatique, théologique, juridique dans les discours et sermons des dévots et renonçants. Il leur revient dès lors de s'abstenir de relater des opinions jugées subversives par les traditionnistes, et de ne pas tenir de confessions religieuses aux articles susceptibles d'être marqués du sceau de l'hérésie.

On voit bien que ce n'est plus tout à fait la sincérité en tant que fruit de la piété célébrée de ces transmetteurs que l'on préfère scruter de près à présent, puisque l'on est formé à la différencier de cette autre forme de sincérité, à la fois neutre par rapport à sa mission de transmission et transparente quant à sa démarche de l'accomplir. En vérité, ce qui est visé c'est la sincérité en tant que qualité participant de la crédibilité de celui qui en est porteur, celle-là même que l'on cultive pour présider à l'acte de transmettre. C'est que l'approche critique est désormais forte de son avancée analytique dont nous avons pu déceler l'empreinte à travers les avis ciblés à l'époque classique. Elle ne se prend pas seulement en main, comme science prépondérante qui se suffit à elle-même, mais elle entend aussi se désolidariser de l'excès de confiance que l'on avait autrefois témoigné à l'endroit de ces renonçants et dévots. Pour elle, il est donc temps de fixer une ligne de démarcation nettement visible entre deux sincérités différentes, compte tenu de leurs objets parfaitement distincts, quoique jusque-là de nature indiscernable, parce que trop entremêlées: d'un côté celle qui, intérieure à la sphère des hommes voués à la tradition, est requise exclusivement dans le domaine de la transmission de hadiths; de l'autre celle, facultative et extérieure à leur sphère, à laquelle réagit la sensibilité du commun des croyants. Pour ce faire, les critiques, dans des dispositions historiques favorables, en possession d'un système de surveillance édifié par leurs maîtres, vont s'astreindre aux règles de contrôle soigneusement élaborées par leurs soins, qu'ils considèrent seules à même de mener conjointement la vérification systématique des chaînes de garants d'une part, et l'évaluation du degré de correspondance entre les isnäds et leurs matns de l'autre. Ces méthodes d'analyse vont connaître leur phase d'affinement et, ce faisant, arriveront à maturité avec les traditionnistes-critiques de la troisième génération, dont les procédés de contrôle, appliqués aux garants à tendance ascétique, feront montre d'une amélioration manifeste par comparaison avec ceux pratiqués par leurs prédécesseurs.

Mais il n'en est pas tout à fait de même du côté des traditionnistes à forte inclination mystique, voire soufie, qui œuvrent, en dépit de leur statut reconnu de traditionnistes, à réhabiliter les figures marquantes de l'ascèse de l'époque préclassique. Nous en voulons pour preuve Abū 'Abd al-Raḥmān 
al-Sulamī et Abū Núaym al-Iṣfahānī - pour ne citer que ces deux auteurs des Tabaqāt dont le rôle était des plus déterminants dans la réhabilitation des personnages ascético-mystiques désavoués par les savants traditionnistes - qui s'étaient employés à restituer, en l'expurgeant des versions négatives d'origine traditionniste ou autre, l'image fabuleuse des ascètes anciens. Ainsi en est-il, comme nous l'avons évoqué, du renonçant d'inspiration mystique que fut Ibn 'Ammār. Le lecteur le méconnaîtrait presque s'il ne commençait par le découvrir que dans les recueils biographiques des traditionnistes. D'un point de vue chronologique, on peut donc supposer que c'est à une période antérieure à celle d'Abū Hāmid al-Gazālī (m. 505/1111) qu'il faudrait faire remonter les tentatives de réhabilitation des renonçants à tendance mystique et des soufis dans le giron du sunnisme. Pourquoi ne serait-ce pas au moment même où les figures de la mystique naissante voyaient leurs idées contestées aussi bien par leurs contemporains traditionnistes que par les défenseurs d'une ascèse et d'une dévotion austères, dépourvues de toute spéculation de subtilité mystique, tels que Gulām Halīl dont nous traiterons plus loin? En redéfinissant les caractéristiques des renonçants d'un côté, et celles des dévots de l'autre, en tant que deux tendances similaires d'une catégorie distincte de transmetteurs, il est évident que les traditionnistes de la troisième génération ont largement contribué à l'émergence d'une réflexion critique radicale dont la vocation était de prendre le distances nécessaire par rapport aux transmetteurs, sans aucune faveur pour cette catégorie afin que l'évaluation de ses transmissions ne doive plus rien à la piété de notoriété publique de ses membres, et qu'ainsi le sens critique, sauf, ait tout son mordant.

\section{Troisième génération}

Avant de passer à la génération suivante, il nous faudrait situer les précédentes, dont nous avons parcouru les personnages d'ascendance ascétique, dans l'histoire de l'évolution de l'écrit et de son support, dans le monde musulman, pour prendre en compte le rôle des formes scripturaires dans la circulation du savoir. Au cours de la première génération, c'était bien évidemment l'oralité qui constituait la voie supérieure de l'enseigement et de la transmission des sciences, avec pour support affectionné, une mémoire auditive vertigineuse, alors que l'écrit, relégué au rôle secondaire, se manifestait sous forme de feuillets ( $\breve{g} u z^{\prime}, p l$. a $\left.\breve{g} z \vec{a}^{\prime}\right)$ et de manuels individuels, en l'absence du livre dans sa forme à venir. Quant à la deuxième génération, elle correspond à la fin de cette période de la compilation et de la consignation par écrit (tadwīn) sans 
soucis d'ordonnancement des matières, et le début de la phase de l'écriture d'ouvrages proprement dits, qui sont ordonnés en chapitres systématiques (tașnif $)^{117}$. C'était aussi l'époque, pour ce qui concerne l'histoire de la discipline du hadith, de l'élaboration des premiers outils techniques à des fins critiques dont l'objet était autant la transmission que les transmetteurs. Quant à cette génération-ci que nous nous apprêtons à franchir, elle correspond à l'époque à laquelle la rédaction des musannafāt était arrivée à un stade très avancé, donnant un nouveau souffle à l'esprit de systématisation dans le domaine du hadith comme dans celui de la critique. C'est au cours de cette période, comme le souligne à juste titre Massignon, que «les fondateurs de la science critique du hadith dénoncent avec indignation divers "faussaires" ${ }^{118}$. Les yeux d'experts que les ascètes et les dévots transmetteurs de hadiths sentaient désormais fixés sur eux, représentaient l'aboutissement d'une succession d'expériences méthodologiques de surveillance et de contrôle des ruwāt. Plus précisément, nous assistons au triomphe final du traditionnisme. Il s'agit sans contredit d'une ère historique dans laquelle se tiennent en maîtres incontestés de la critique, des traditionnistes illustres aux compétences analytiques amendées, dont voici les plus célèbres que nous citons dans l'ordre chronologique: Ibn Sa d kātib al-Wāqidī (m. 230/845), Yahyā b. Ma īn (m. 233/848), 'Alī b. al-Madīnī (m. 234/849), Aḥmad b. Hanbal'119, 'Ubayd Allāh Abū Zur'a l-Rāzī (m. 264/878), Abū Hātim al-Rāzī (m. 277/889) et son fils Ibn Abī Hātim (m. 327/939). Ce faisant, les falsificateurs de hadiths de tous bords, y compris les zuhhād à popularité grandissante, semblent avoir affiné, de leur côté, les subterfuges de camouflage dans l'art de la fabrication des isnäds comme dans celui de l'invention des matns.

Il subsistait, par conséquent une certaine symétrie qui continuait de façonner le rapport dynamique, quoique paradoxal, qu'entretenaient les uns avec les autres. La part belle qui revenait antérieurement, dans la forgerie de hadiths, aux rapporteurs d'origine majoritairement bașrienne se confirmera nettement au cours de cette période au travers du personnage de Gulām

117 Cf. I. Goldziher, Études sur la tradition islamique (Muhammedanische Studien, II) trad. Léon Bercher, Paris, Maisonneuve, 1984, p. 252-53; G. Schoeler, Écrire, p. 55, 71-89 et passim; voir notre thèse L. Daaif, Ibn Hanbal entre traditionnisme et droit légal, SorbonneNouvelle Paris III, 2004, p. 23, 223; S.C. Lucas, Constructive Critics, p. 67 sq., 73 sq.

118 L. Massignon, Essai, p. 120.

119 Scott C. Lucas, s'est employé à mettre en lumière le rôle prépondérant de ces trois imams (à l'exclusion d'Ibn al-Madīnī) dans le triomphe final du traditionnisme, triomphe qui n'était pas seulement dû à al-Šāfíi et à ses thèses uṣūlites pro-traditionnistes, cf. id., Constructive Critics, surtout p. 157-217, 287-325. 
Halill, éminent ascète auquel les critiques des rapporteurs décernent le plus haut grade en matière de wad ' au regard de tous les rapporteurs renonçants. Mais avant de nous intéresser à ce dernier, portons-nous sur quelques figures ascétiques auxquelles il a succédé, et qui furent de célèbres forgeurs de hadiths, mais aussi de fervents dévots aux intentions pieuses irréprochables. Dans un large éventail de transmetteurs ascètes de cette époque, qui pratiquaient le renoncement au moins dans l'une de ses trois conduites de base, jeûne, veille et silence, nous nous sommes particulièrement intéressé à ceux d'entre eux dont les relations étaient fréquentes et plus ou moins cordiales avec les traditionnistes contemporains de leur milieu, ou qu'ils ont pu côtoyer durant leur déplacement. Ainsi nous serait-il possible de les cerner en tant que rapporteurs de traditions au moyen des condamnations dont ils faisaient l'objet de la part de leurs critiques qui les avaient connus en personne, et qui avaient pu aisément, de par leur proximité, les démasquer en perçant à jour leurs artifices dans l'art de l'invention des hadiths. C'est donc à travers le prisme de l'histoire, telle qu'elle fut écrite par les traditionnistes, que nous nous ferons une idée approximative de l'histoire réelle des ascètes et dévots en tant que garants de hadiths. Certes, ce passage obligé a l'inconvénient de nous renvoyer, en général, une image terne de cette catégorie de garants, mais son incommodité est parfois propice à des interrogations qui excèdent le cadre historique irréductible du sunnisme traditionniste. La solution à ce qui nous préoccupe ici, n'aurait d'autre lieu où s'enraciner pour satisfaire aux règles normatives de l'écriture de l'histoire que celui, quasi impénétrable, qui s'offre en contrepoids à la réflexion qui se doit d'osciller entre la matière historique disponible et l'histoire à réécrire.

Le premier personnage dont il nous faut faire la présentation en partant des plus anciens aux plus récents ascètes influents de cette troisième génération, est Abū 'Abd Allāh Aḥmad b. Harb al-Zāhid de Nīsābūr, qui fut l'une de ces autorités mystiques fort influentes de son époque. Grand renonçant, mais aussi homme de conduite pieuse (hasan al-taríqa), entièrement rompu à une vie dévote désintéressée et à l'observance stricte (nusk). Il eut même pour maître en science de transmission des traditions le grand Ibn 'Uyayna, ainsi que d'illustres traditionnistes de Nīsābūr ${ }^{120}$. Jusqu'à sa mort en $234 / 849$, nous dit-on, toutes ses nuits n'étaient que veille en dévotion et adoration de $\mathrm{Dieu}^{121}$. Lors de ses nombreux déplacements dans les grandes villes, y compris dans Bag̉ād, chacun de ses passages donnait lieu à de grands rassemble-

${ }^{120}$ Cf. al-Bag̀dādī, Tảrīh, IV, p. 118, n 1785; Ibn al-Ğawzī, al-Muntazam fì Tả rìh al-umam wa-l-mulūk, éd. Muh. 'Abd al-Qādir 'Ațā \& Mușțafā 'Abd al-Qādir 'Ațā, Beyrouth, Dār alkutub al-ilmiyya, 1992/1412, XI, p. 210, n 1369.

121 Ibn al-Gawzī, al-Muntazam, XI, p. 210. 
ments de disciples et admirateurs qui venaient massivement écouter ses conseils et s'attirer en même temps la bénédiction de Dieu en l'approchant. D’aucuns parmi les autorités en vue, comme Yahyā b. Yạ̣yā, en vantaient les mérites et les prodiges, si bien qu'ils l'identifiaient comme l'un des Substituts (badal, pl. abdāl) de leur époque tant son rang spirituel était élevé ${ }^{122}$.

Toutefois, l'avis des critiques à son égard ne souffrent le moindre désaccord en ce qui concerne sa qualité de piètre transmetteur, voire même sa probité suspecte en tant que garant, en mettant au jour plusieurs hadiths, répandus par lui, jugés rares (garīb). D’autre part Ahmad b. Harb ne devait pas seulement un tel bilan désastreux au manquement aux règles de la transmission qu'on lui avait effectivement reproché, mais aussi au fait d'avoir été un adepte de certaines thèses murği ites. Cependant, en dépit de cette évaluation plutôt négative, une large majorité d'entre les gens du hadith s'était abstenue d'émettre un avis d'interdiction formelle à se référer aux traditions qu'il a rapportées. En d'autres termes, celles-ci devaient être estimées non pernicieuses pour la communauté (wa-lam yutrak) ${ }^{123}$.

$\mathrm{Au}$ nombre des forgeurs ascètes notoires, une place de choix devait revenir au fondateur de l'école karrāmite, Abū 'Abd Allāh Muhammad b. Karrām qui mourut à Jérusalem en 255/863, après avoir été emprisonné, à deux reprises, à Nīsābūr par les gouverneurs successifs de cette ville, les Ṭāhirides: le père, Ṭāhir b. 'Abd Allāh et le fils, Muhammad b. Ṭāhir ${ }^{124}$. Pour al-Ḍahabī (m. 748/1348), Ibn Karrām fut d'abord un célèbre zāhid, versé dans les sciences gnostiques, mais il n'en faisait pas moins partie des dévots d'obédience murği'ite ('ubbād al-murğ̌ia) ${ }^{125}$; tandis qu'al-Šahrastānī (m. 548/1153) ne voyait dans son ascétisme qu'un vulgaire déguisement (mutanammis) qu’il se donnait pour mieux répandre ses funestes doctrines «parmi les peuplades

122 Cf. al-Bag̀dādī, Tả rīh, IV, p. 119; Ibn al-Ğawzī, al-Muntazam, XI, p. 210; al-Dahabī, Mizān, I, p. 89, n 329; Ibn Hağar, Lisān, I, p. 150. À notre connaissance, le Muntazam reste, pour le moment, la seule référence à attribuer ce témoignage à Yahyā b. Ma īn, car c'est à Yahyā b. Yahyā que les trois autres sources l'attribuent. Sachant que la source principale de toutes ses références est Tả rìh Bagdäd, il est donc probable que ce soit une erreur de l'éditeur, à moins que ce ne soit celle de l'auteur lui-même. D'autre part, il est difficilement soutenable qu'Ibn Ma'īn, qui fut traditionniste et critique d'autorité irréprochable aux yeux de la quasi-totalité des gens de la tradition, se soit livré à des avis critiques sur des questions d'ordre mystique.

123 Al-Dahabī, Mìzān, I, p. 89.

${ }_{124}$ Ibn al-Ațīr, al-Lubāb fì tahdīb al-ansāb, Beyrouth, Dār Șādir, 1400/1980, III, p. 89. D’après al-Ṣafadī, le premier emprisonnement, qui eut lieu sous Ṭāhir b. 'Abd Allāh, dura huit ans. À son retour de La Mecque à Nīsābūr, il fut à nouveau emprisonné pour hérésie par le fils du premier, Muhammad b. Țāhir, pour une longue période que les historiens appellent sa mị̣na, cf. al-Ṣafadī, al-Wāfî̀ bi-l-wafayāt, éd., H. Ritter \& alii, Beyrouth, Dār Șādir/Stuttgart, Franz Steiner, Wiesbaden, 1949-2008, IV, éd., Sven Dedering, 1981, p. 376.

125 Al-Dahabī, al-'Ibar, II, p. 10. 
incultes ${ }^{126}$. Le maître d'Ibn Karrām, celui qui l'initia à l'ascèse et au détachement de la vie matérielle n'était autre qu'Ahmad b. Harb ${ }^{127}$ dont nous avons parlé plus haut, et que les Karrāmites revendiquèrent comme adepte de leur doctrine théologique professant l'anthropomorphisme (tašbīh) et le corporéisme $(\text { tă̆gsim })^{128}$.

Au jugement d'Ibn Hibbān (m. 354/965), les hadiths rapportés par d'Ibn Karrām n'ont aucune valeur probante (sāqiț al-ḥadīt), d'autant plus qu'il les rapportait de transmetteurs fort marginaux. Deux d'entre eux étaient des imposteurs patents, répertoriés et connus de tous les critiques, qui leur attribuaient l'invention d'environ cent milles hadiths apocryphes, à savoir Ahmad b. 'Abd Allāh al-Ğuwaybārī et Muhammad b. Tamīm al-Sa dī (al-Fāryābīi) ${ }^{129}$. La plupart des recueils historiographiques mettent l'accent sur la condamnation indirecte d'Ibn Karrām par al-Buhārī, bien qu'elle soit curieusement absente de l'œuvre critique majeure de ce dernier, al-Ta’rīh al-kabìr. D'après Abū l-Abbās al-Sarrāğ, témoin et rapporteur de cette histoire, ayant lu la lettre que lui aurait adressée Ibn Karrām dans l'intention d'obtenir son avis critique sur certaines traditions dont celle-ci : «la foi n'augmente ni ne diminue», al-Buhārī aurait noté au dos de la lettre en guise de réponse: "Celui qui a transmis ceci mérite d'être bastonné durement et jeté en prison pour une longue durée ${ }^{130} »$. Une telle définition de la foi était, en effet, aux antipodes du credo orthodoxe pour qu'Ibn Karrām pût espérer un avis favorable ou tout

126 Al-Šahrastānī, al-Milal wa-l-niḥal, éd. A.F. Muhammad, Beyrouth, Dār al-kutub al-ilmiyya, 1410/1990, I, p. 28; id., Livre des religions et des sectes, trad. intro. et notes par D. Gimaret \& G. Monnot, Peeters/Unesco, 1986, I, p. 147.

127 Al-Ṣafadī, al-Wāfì, IV, p. 376; al-Dahabī, Siyar, XI, p. 524, nº 146.

${ }^{128}$ Ibn al-Atīin, al-Lubāb, III, p. 89. Ibn al-Ațīr souligne les particularités hérétiques que contient cette doctrine: «[...] que Dieu très haut est un corps (̆gism) [...] qu'Il se trouve dans un lieu particulier (makān mabșūss), surplombé de très près par Son Trône», ibidem. Cf. al-Šahrastānī, al-Milal, I, p. 99; id., Livre des religions et des sectes, I, p. 347: "[..] que le Dieu qu'il adorait est établi sur le Trône, et qu'il se trouve [en essence] dans la direction du haut. Il

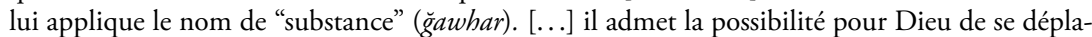
cer, de changer de lieu, de descendre». Voir aussi al-Ṣafadī, al-Wâfí, IV, p. 376; Ibn al-'Imād, Šadarāt, II, p. 131.

${ }^{129}$ Ibn 'Asākir, Ta’rīh Dimašq, LV, n 6930, p. 127; al-Ṣafadī, al-Wâfî, IV, p. 375; al-Dahabī, Siyar, XI, p. 523; id., Mizān, IV, nº 8103, p. 21; Ibn Hağar, Lisān, V, nº 1185, p. 352. Des plus célèbres hadiths que l'on doit à Ibn Karrām par le truchement d'al-Ğuwaybārī, qu'il cite sous une nisba déguisée, al-Šaybānī, nous citerons celui-ci qui porte sur l'importance de la science ( $\left.{ }^{\mathrm{i}} \mathrm{lm}\right)$ en islam, connu de tous et cité à outrance même dans les milieux savants: "Cherchez la science fût-ce en Chine" uṭlubū l-ilm wa-law bi-l-Ṣìn, cf. al-Ḍahabī, Mìzān, I, p. 107; Ibn Hağar, Lisān, I, p. 193. Voir infra, note 187. Ces chiffres mirobolants, toujours arrondis en milliers, auxquels les traditionnistes estiment ses hadiths forgés n'ont d'autre intérêt, dans la mise en garde des croyants contre les forgeurs, que de s'octroyer le bon rôle, celui des vigiles de la communauté qui ont réussi à débusquer par centaines de milliers les inventions des ennemis intérieurs du sunnisme.

${ }^{130}$ Ibn 'Asākir, Tả rīh, LV, p. 129; al-Dahabī, Mìzān, IV, p. 21. 
bonnement indulgent de la part d'al-Buhārî́ ${ }^{-131}$. Au contraire, la condamnation du matn n'en était que plus catégorique, au grand dam d'Ibn Karrām dont ce fut précisément le dogme. Et même s'il remontait directement au prophète via Ibn Šihāb al-Zuhrī, puis Sālim et enfin le père de celui-ci, cet isnād, visiblement ininterrompu (marfüu), n'en était pas moins un isnād trafiqué aux yeux d'al-Buhārī qui y avait décelé le lien improbable, voire impossible entre une chaîne de garants bien trop parfaite et un contenu inadmissible.

Néanmoins, il y aurait lieu d'être dubitatif quant à la réalité historique de cette correspondance épistolaire entre les deux hommes. On est en droit d'y voir tout simplement une pure invention, ou une réécriture de cet épisode par les traditionnistes eux-mêmes, qui chercheraient, en mettant sciemment en scène la quête désespérée de l'approbation des autorités sunnites par Ibn Karrām, à attirer l'attention sur l'importance du rôle de ces autorités même pour une figure aussi marquante de l'époque comme l'était ce dernier. Il y va du prestige de l'institution du hadith, d'une certaine manière, qui revendiquerait ses marques d'autorité même vis-à-vis d'une personne indépendante des canaux officiels de transmission, dont l'activisme religieux ciblait le bas peuple. D'ailleurs, plus d'un siècle après Ibn Karrām, la conclusion d'Ibn Hibbān, dont la notice biographique est reprise par tous les critiques ultérieurs, semble aller dans ce sens, lorsqu'il décrit celui-ci en faisant allusion à son livre Le châtiment de la tombe ('Ad̄āb al-qabr) ainsi ${ }^{132}:$ "Il en était réduit à glaner des doctrines théologiques des plus néfastes, et à grappiller des hadiths des plus faibles (apocryphes) ${ }^{133}$.

Mais outre cet aspect relatif à la forgerie des traditions que l'on dénonce chez Ibn Karrām, il aurait été, semble-t-il, comme bien d'autres forgeurs de son époque, consciencieusement en faveur de cette pratique. Il ne voyait pas d'inconvénient à ce qu'un transmetteur puisse recourir à l'invention des

131 Dans le Coran $(8,2)$, la définition du véritable croyant sur laquelle se fondent les orthodoxes entre littéralement en contradiction avec le matn de ce hadith rapporté par Ibn Karrām: «Les croyants sont ceux dont le cœur frémit quand Dieu est invoqué et dont la foi augmente quand Ses signes leur sont communiqués». Sur sa doctrine de la foi cf. al-Šahrastānī, al-Milal, I, p. 104. Al-Ṣafadī, lui, écrit: «Dans sa doctrine, il est dit que la foi est parole sans connaissance (bilā márifa)», id., al-Wâfí, IV, p. 376. Contrairement aux Murği ites qui dissocient la foi et les œuvres en remettant à Dieu le soin de reconnaître les Siens, l'orthodoxie, elle, inclut les actes dans la foi qui augmente avec l'obéissance $\left(t \bar{a}^{-} a\right)$ et diminue avec la désobéissance (másiya).

${ }^{132}$ C'est son œuvre la plus souvent évoquée et à laquelle se réfère al-Šahrastānī pour rappeler ses positions théologiques. Al-Ṣafadī affirme qu'étant de peu de science, il n'aurait même pas été l'auteur de ses propres livres, qui auraient été rédigés par Mảmūn b. Aḥmad al-Sulamī, cf. id., al-Wäfí, IV, p. 376.

133 Al-Ṣafadī, al-Wāfì, IV, p. 375; al-Dahabī, Siyar, XI, p. 523; Ibn Hağar, Lisān, V, nº 1185 , p. 352 . 
hadiths à partir du moment où il n'a en vue que l'incitation des croyants à l'accomplissement des bonnes actions et leur dissuasion d'en commettre de mauvaises ${ }^{134}$. Reste que cette seconde dénonciation est loin de faire l'unanimité dans les rangs des critiques des riğăl. Si l'on prend, par exemple, le cas d'Ibn Katīir (m. 774/1373) on remarque qu'il ne s'est pas trop attardé sur ce sujet, se contentant de rappeler à titre d'information sans autre développement: "[qu'] on lui attribue une attitude licencieuse en ce qui concerne l'invention des hadiths et leur mise sur le compte de l'Envoyé [de Dieu] et de ses Compagnons » ${ }^{135}$. La position d'Ibn 'Asākir (m. 571/1175), qui est antérieure de deux siècles, est bien plus indulgente en comparaison. Après avoir mentionné les deux imposteurs qui servaient à Ibn Karrām de rapporteurs, al-Ğuwaybārī et Ibn Tamīm al-Sa '́ī (al-Fāryābī), il conclut presque à la décharge d'Ibn Karrām par ces mots: «S'il les avait bien connus, il se serait abstenu de rapporter des traditions d'eux ${ }^{136}$. En conséquence de quoi, Bosworth n'a pas tout à fait tort d'avoir établi un lien causal entre le fait qu'Ibn Karrām se fiait à des menteurs notoires et l'étiquette de «forgeur de hadiths» que lui collaient, par la suite, ses détracteurs traditionnistes ${ }^{137}$.

Dans leur répertoire biographique, les historiographes font souvent état d'un traditionniste harrānite, qui répondait au nom de Wahb b. Hafṣ al-Bağalī (m. 250/864 $)^{138}$. Ils le présentent comme un personnage foncièrement pieux, menant une vie vertueuse, d'une conduite ascétique telle qu'il se serait interdit d'adresser la parole aux humains durant une vingtaine d'années ${ }^{139}$. Mais en dépit de ses qualités ascétiques incontestables, la condamnation de ses hadiths a été confirmée à l'unanimité. Voici l'un des hadiths de son invention qu'il faisait remonter au Prophète comme transmission ininterrompue par le biais du Compagnon 'Abd Allāh b. 'Umar (m. 74/693): "Celui que Dieu a

${ }^{134}$ Muhammad Z. Siddiqi, Hadith Literature. Its Origin, Development and Special Features, Cambridge, The Islamic Texts Society, 1993, p. 36.

135 Cf. id., al-Bidāya, XI, p. 22-23.

136 Ibn 'Asākir, Ta’rīh, LV, p. 128: wa-law 'arafahumā la-amsaka 'an al-riwāya 'anhumā. Ce qui fut aussi le constat d'Ibn Hağar qui qualifie Ibn Karrām de muigaffal, dupe, dans son commerce avec al-Ğuwaybārī, cf. id., Lisān, I, p. 193: wa-kāna bn Karrām yasmàuhā wa-kāna mugaffalan.

137 C.E. Bosworth, «Karrāmiyya », $E I^{2}$, IV, p. 694

138 Cette date est tantôt proposée comme étant celle de sa mort (cf. al-Dahabī, Mĩzān, IV, p. 351, $\mathrm{n}^{\circ}$ 9425), tantôt comme étant celle à laquelle remonte la dernière transmission qu'il aurait faite (cf. Ibn Hağar, Lisān, VI, p. 229, n 819). Quant à son nom, lui aussi n'est pas exempt de confusion, car il se présente parfois ainsi: Wahb b. Yahyā b. Hafṣ, dans Mizān, IV, p. 355, n 9436; Lisān, VI, p. 234, n 832. Selon Ibn 'Adī, il avait pour kunya Abū l-Walīd, cf. Lisān, ibid.

${ }^{139}$ Cf. al-Ḍahabī, Mìzān, IV, p. 355 ; Ibn Hağar, Lisān, VI, p. 229; Burhān al-Dīn al-Hạabī, al-Kaśf, p. $456, \mathrm{n}^{\circ} 827$. 
privé de sa vue, il Lui incombe par devoir (haqqan wäğiban) de faire en sorte que ses yeux ne croisent jamais le feu de la géhenne [dans l'au-delà] ${ }^{140}$ ". L'autorité religieuse à laquelle se référaient, en premier lieu, les critiques pour jeter le discrédit sur al-Bağalī était le grand hăfiz attitré de la région de Harrān, al-Husayn Abū 'Arūba (m. 310/922) $)^{141}$, qui, ayant effectivement démasqué les "mystifications» de ce dernier, l'avait traité ouvertement de menteur. Se fondant sur l'avis critique d'une autorité fiable, d'origine harrānite de surcroît, Ibn 'Adī a fait observer également que toutes les transmissions d'al-Bağalī sont suspectes (manākīr $)^{142}$. Le portrait qu'Ibn Hibbān nous a brossé de lui mérite d'être cité, parce qu'il cerne d'assez près les traits caractéristiques du personnage: "C'était un vieillard distrait, écrit-il, qui «transposait (yuqallibu)» les traditions (abjbār) sans s'en rendre compte. Ce faisant, il y commettait des erreurs, [parce qu'] il n'y entendait rien. De plus, il pratiquait le vol du hadith (yasriqu l-haditit) ${ }^{143}$.» Il en va de même de l'avis critique d'al-Dāraquṭnī qui corrobore les jugements de ses prédécesseurs en qualifiant al-Bağalī de forgeur de hadiths ${ }^{144}$.

Mais c'est le cas exceptionnel de l'ascète kūfien Sulaymān b. 'Amr Abū Dāwūd al-Nahái l- l'Ámirīîn ${ }^{145}$, souvent traité dans les sources de la critique des riğăl, qui figure l'exemple type de personnages ascétiques qui soient les plus activement impliqués dans l'invention des hadiths en cette troisième génération. La plupart des notices biographiques nous le dépeignent par le menu, sous les traits d'un dévot de premier plan. C'était une personne qui jeûnait tous les jours, et consacrait en outre toutes ses nuits à l'adoration de Dieu ${ }^{146}$. Toutefois, sa conformité au dogme théologique sunnite laisse à désirer si l'on en croit le témoignage d'Ibn Hibbān et d'Ibn 'Adī, d'après lesquels al-Naha' ī

140 Al-Ḍahabī, Mizān, IV, p. 355; Ibn Hağar, Lisān, VI, p. 234. Dans un autre hadith qu’il rapporte, il fait dire au prophète: «Tuer un gros lézard équivaut à tuer un diable», Ibn Hağar, Lisān, VI, p. 234.

${ }_{141}$ Sunnite de forte inclination politique šĩ ite, il avait en horreur les Umayyades. Il fut l'un des maîtres d'Ibn Hibbān et d'Ibn 'Adī, cf. al-Dahabī, Siyar, XIV, p. 510-2, nº 285.

${ }_{142}$ Qui le rapporte d'un autre traditionniste harrānite, Abū Badr Aḥmad b. Huālid, preuve qu'il a été démasqué par des critiques qui le côtoyaient de très près, cf. Ibn Hağar, Lisān, VI, p. 229-30.

143 Ibn Hağar, Lisān, VI, p. 229.

144 Al-Ḍahabī, Mĩzān, IV, p. 351, 355; Ibn Hağar, Lisān, VI, p. 229; Burhān al-Dīn, al-Kašf, p. 456.

145 Malheureusement, aucune source ne nous renseigne sur sa date de mort, ni al-Nasāà,$K$. al-Ḍiafä', p. 120, n² 260, ni al-Dahabī, Mìzān, II, p. 216-18, n 3495, ni Burhān al-Dīn, al-Kašf, p. 202-03, n 331, ni Ibn Hağar, Lisān, III, p. 97-99, n 332. Seule certitude c'est qu’il est le contemporain d'Ibn Hạbal (m. 241/855) et du condisciple de celui-ci Ishạa b. Rāhawayh (m. 238/853).

${ }_{146}$ Al-Dahabī, Mizzän, II, p. 216-8, n 3495, p. 218; Ibn Hağar, Lisän, III, p. 97-9, n 332, p. 98 . 
professait un dogme imprégné de thèses hétérodoxes qadarites ${ }^{147}$. Quant à sa contribution dans la riwāya, toute faite de traditions inventées de toutes pièces, il l'a consacrée à une spécialité originale, peu explorée jusque-là par les invétérés de la forgerie de hadiths, à savoir la diététique. Dans plusieurs hadiths de son cru, al-Naḩa ì vante, en expert nutritionniste attitré, les propriétés nutritives de tel légume ou tel fruit, et parfois de telle boisson ou tel liquide comme le vinaigre et l'huile ${ }^{148}$. Il faut lui concéder une autre originalité qui se constate tout autant dans un autre domaine où il semble être l'un des premiers à exceller. En effet, al-Naha î forgeait également des hadiths qui mettent en valeur certains métiers d'artisan, en l'occurrence le filage $(\dot{g} a z l)$ et le tissage (hiyāka ${ }^{149}$. Ce qui ne l'empêchait pas d'être à l'origine d'autres traditions relatives aux ablutions rituelles et à l'intercession ( $\left.\check{s}^{a} a \tilde{a}^{-} a\right)$ du Prophète au Jour du Jugement dernier ${ }^{150}$.

Ibn Hanbal, qui aurait conversé avec lui lors d'une rencontre fortuite, l'avait depuis nommément qualifié de forgeur de hadiths ${ }^{151}$. C'est peut-être même le personnage ascétique à l'encontre duquel se sont prononcés négativement en masse tous les critiques, pour lui assigner le grade suprême en matière d'invention des traditions en le surnommant le menteur par excellence de la cité de Nahá (kaddāa Nahba $)^{152}$. Et c'est par Ibn Hağar (m. 852/1448-9), que nous apprenons qu'ils seraient plus de trente spécialistes en science de l'improbation et de l'approbation (al-ğarh wa-l-ta'dìl), anciens et tardifs confondus, à l'avoir incorporé dans la liste des forgeurs (wadd̄̄i $\bar{u} n$ ) notoires ${ }^{153}$.

Voici à titre indicatif, les plus importantes sentences qui aient été prononcées à son endroit par d'illustres critiques, citées suivant l'ordre chronologi-

${ }_{147}$ Sur le propos d'Ibn Hibbān, cf. Ibn Hağar, Lisān, III, p. 98 et Burhān al-Dīn, al-Kašf, p. 202, sur celui d'Ibn 'Adī, cf. al-Dahabī, Mizā̃n, II, p. 217.

${ }_{148}$ Citons l'une de ses inventions les plus répandues en matière diététique: "Quelles succulentes sauces le vinaigre et l'huile [...]", ni'ma l-idām al-bुall wa-l-zayt, cf. al-Dahabī, Mīzān, II, p. 217. Il attribue un autre habar de son invention au quatrième calife 'Alī b. Abī Tāàib (m. 40/661). Il s'agit d'une tradition, restée très célèbre dans les milieux populaires, qui est encore souvent évoquée à table de nos jours, où sont vantés les principes nutritifs de la grenade: «Prenez la grenade. Mangez-la avec sa chair (interne). Elle est le tanneur de l'estomac", 'alaykum bi-l-rummān. Kulūbu bi-šăḅmihi fa-innahū dabbāg al-ma ida, cf. ibid.

149 Cf. al-Dahabī, Mizān, II, p. 217.

150 Sur les ablutions rituelles (wud̄̄), cf. al-Dahabī, Mĩzān, II, p. 216; Ibn Hağar, Lisān, III, p. 97. Sur l'intercession, al-Dahabī, ibid., p. 217; Ibn Hağar, ibid., p. 98.

151 Ibn Abī Hatim, Garh, IV, p. 132, n 576; al-Dahabī, Mìzān, II, p. 216; Burhān al-Dīn, al-Kašf, p. 202.

152 Al-Ardabīlì, Ğàmi al-ruwāt wa-izāḥat al-ištibāhāt 'an al-țuruq wa-l-isnād, Beyrouth, Dār al-aḍā', 1403/1983, I, p. 382 $2^{\mathrm{a}-\mathrm{b}}, \mathrm{n}^{\circ} 3126$.

${ }^{153}$ Ibn Hağar, Lisān, III, p. 99: Qultu [...] wa-nasabahu ilā l-wad' min al-mutaqaddimìn wa-l-mutảabbuirin [..] fawq al-talātīn nafs, y compris Muslim dans son Șaḥ̄ḥ, p. 7. 
que dégressif de la date de mort de leur auteur: Yazīd b. Hārūn al-Wāsiṭi (m. 206/821): «transmettre [des hadiths] de lui est interdit ${ }^{154}$ »; Ibn Ma īn: "Il était le plus menteur des rapporteurs ${ }^{155}$ »; Ibn al-Madīnī: "C'était un Antéchrist (da $\breve{g} \breve{g} \breve{a} l)^{156}$ »; Isḥāq Ibn Rāhawayh (m. 238/853): "C'était le plus grand menteur que je connaisse en ce bas-monde ${ }^{157}$ »; al-Buhārī (m. 256/870) : "[Il était] réputé pour son mensonge ${ }^{158}$; Abū Zura a 1-Rāzī 1-Kabīr

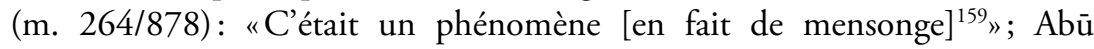
Dāwud al-Siğistānī (m. 275/888) : "[C'était] un rapporteur dont les hadiths doivent être rejetés ${ }^{160} »$; Abū Hātim al-Rāzī (m. 277/890): «[Rapporteur] dont il faut rejeter les hadiths. Il était un imposteur ${ }^{161}{ }$; al-Hākim al-Nīsābūrī : (m. 405/1014): "En ce qui me concerne, nul doute qu'il fut inventeur de hadiths, en dépit de l'austérité outrancière dont il faisait preuve, et les œuvres cultuelles qu'il accomplissait ${ }^{162}$ ».

Et pour mieux mettre en relief la gravité du cas d'al-Naha ${ }^{i}$, il conviendrait de mentionner le témoignage du ḥāfiz 'Uțān b. Abī Šayba (m. 239/853) qui nous fait remarquer que même le grand magistrat de Kūfa, Hafṣ b. Giyāt al-Naḩa î (m. 194/889), traditionniste d'ordinaire très réfractaire à tout jugement critique, s'était prononcé clairement, et à titre exceptionnel, contre al-Naha ${ }^{-163}$. Son témoignage se veut précisément un argument péremptoire qui confirme la sentence consensuelle à l'encontre de ce dernier, puisqu'il provient d'un critique, réputé s'être scrupuleusement refusé de traiter de menteur quiconque transmettait des hadiths.

Malgré cela, la forgerie des hadiths par les renonçants qui frôlaient l'indécence à cette époque, n'atteignit pas son paroxysme avec ces deux derniers personnages qui deviendront presque secondaires en comparaison du personnage central de Gulām Halīl dont il est systématiquement question dans les recueils des critiques des transmetteurs. Il s'agit d'Abū 'Abd Allāh Aḥmad b. Muhammad b. Gālib (m. 275/888), célèbre ascète, qui se trouve être, lui

154 Al-Dahabī, Mìzān, II, p. 216.

155 Al-Dַahabī, ibid., aussi Ibn Abī Hātim, Garh, IV, p. 132: "Il n’est rien, il ment et forge des hadiths"; Burhān al-Dīn, al-Kašf, p. 202: «réputé pour sa forgerie».

156 Ibn Hağar, Lisān, III, p. 99.

157 Ibidem.

158 Al-Buhārī, K. al-Tảrīh, IV $\left(\mathrm{II}^{2}\right)$, p. 29, n 1854, se référant à son maître Ibn Rāhawayh et à Qutayba b. Saīid (m. 240/854).

159 Ibn Abī Hātim, Ğarḥ, IV, p. 132-3: Kāna àya.

160 Al-Nasāì, K. al-Duiafä, p. 120, n 260.

161 Ibn Abī Hātim, Garh, IV, p. 132.

162 Burhān al-Dīn, al-Kašff, p. 202; Ibn Hağar, Lisān, III, p. 99.

163 Ibn Muhriz, Márifat al-rĭgāl an Yahyā b. Ma'in, II, p. 245, nº 843. 
aussi, d'origine bașrienne ${ }^{164}$. On le présume d'obédience hanbalite, mais son appartenance au hanbalisme n'est pas établie d'une manière convaincante et reste encore sujet à débat entre les spécialistes anciens et contemporains ${ }^{165}$. C'était un moraliste respectable à la tête d'un courant ascétique très répandu à Bağdād, ville où il jouissait auprès du menu peuple d'une immense notoriété d'homme pieux ${ }^{166}$. Grâce au soutien que lui apportaient sa première admiratrice, la mère du calife al-Mu'tamid (256/870-279/892), et le frère de celui-ci, al-Muwaffaq (m. 278/891), véritable détenteur du pouvoir ${ }^{167}$, Gulām Halīl fit "décréter des poursuites judiciaires contre des soufis extrémistes ${ }^{168}$ " dans toute la ville de Bagdād. À ses yeux, l'amour de Dieu que prônaient les mystiques est un amour excessif qu'il fallait bannir ${ }^{169}$. Sa conception de l'ascèse était hermétique à toutes les spéculations métaphysiques auxquelles s'adonnaient ses contemporains mystiques, dans la mesure où il ne tolérait, pour toute relation entre le croyant et son Seigneur, que le précepte cultuel qui repose entièrement sur la crainte de Dieu (al-ḩawf $)^{170}$.

164 Ibn al-Nadīm, al-Fihrist l-[Ibn] al-Nadìm, éd. Riḍa Tağaddud, 3 e éd., Téhéran, 1393/1973, réimp. Beyrouth, Dār al-masīra, 1988, p. 237, est le seul à le mentionner sous le nom de 'Abd Allāh b. Ahmad. Or toutes les références qui vont suivre le tiennent pour Abū 'Abd Allāh Ahmad b. Muhammad. Dans son article "Mawāqif al-fuqahā’ min al-șūfiyya», Hawliyyāt al-Ğämi a l-tūnisiyya, XXXIX (1995), p. 3-63, Tawfīq b. 'Āmir a tronqué son nom en le citant toujours sous le nom de Aḥmad b. Hālid b. Mirdās, et l'a fait mourir de surcroît à une date erronée, en l'an 262 de l'hégire, cf. ibid., p. 18, note 37.

${ }_{165}$ En effet, il ne figure pas dans les Tabaqāt al-ḥanābila d’Ibn Abī Yàlā, établi par Muḥammad Hāmid al-Fiqī, Le Caire, Maṭba at al-sunna l-muhammadiyya, 1371/1952, réimp., Beyrouth, Dār al-márifa, s.d. Aussi n'a-t-il jamais été qualifié de hanbalite par al-Ḍahabī non plus dans Siyar, XIII, p. 282-85, n 136. Et Fuat Sezgin, pour sa part, avoue n'avoir rien trouvé de consistant dans les sources prosopographiques qui appuierait la thèse de son affiliation à l'école juridique d'Ibn Hanbal, cf. GAS, I, p. 511. Sur cette question on peut consulter les développements de C. Melchert, "The Hanābila and the Early Sufis", Arabica, XLVIII/3 (2001), p. 361-2.

166 Cf. al-Dahabī, Siyar, XIII, p. 283; aussi J. van Ess, Theologie, IV, p. 284: "Er hatte sich in Bagdād offenbar als Volksprediger eingeführt." Voir C. Melchert, "The transition from asceticism to mysticism ", p. 65.

${ }_{167}$ Abū Ahmad Muhammad b. al-Mutawakkil est le frère du calife al-Mu'tamid et le père du calife al-Mu'tạ̣iḍ bi-llāh, voir al-Ḍahabī, Siyar, XIII, p. 169-70, n 100. Une autre perle est encore à déplorer dans l'article de Tawfíq b. 'Āmir: il prend al-Muwaffaq pour un calife 'abbāside: al-Muwaffaq bi-llāh al-ḩalīfa l-'abbāsī, cf. id., "Mawāqif al-fuqahā'», p. 18.

168 L. Massignon, Recueil de textes inédits concernant l'histoire de la mystique en pays d'Islam, Paris, P. Geuthner, 1929, p. 212.

169 L. Massignon, La passion d'al-Hallajj, martyr mystique de l'Islam, Paris, Gallimard, 1975, I, p. $120-21$.

${ }_{170}$ Pour contrecarrer la doctrine de l'Amour divin prêchée par les soufis, en l'occurrence par Abū l-Husayn al-Nūrī (m. 295/907), qui dut fuir Bağdād pour aller se réfugier à Raqqa, suite au procès désormais associé au nom de Gulām Hulīl «mihnnat Gulām Halīl», celui-ci était allé jusqu’à soutenir que l'amour de Dieu est une innovation blâmable (bid'a), et qu'au lieu de cela 
Ce fut un savant religieux très distingué ${ }^{171}$ auquel Ibn al-Nadīm (m. 380/990) attribue d'ailleurs plusieurs livres, dont certains portent sur les prières rituelles et les oraisons qu'il convient au croyant d'adresser à Dieu, et d'autres où sont recueillis ses sermons publics dans lesquels il prêche le détachement austère et le dénuement total dans la vie d'ici-bas ${ }^{172}$. Il est souvent décrit comme un fervent défenseur de la sunna, dont la profession de foi ('aqida) ne le cède en rien à celles des maîtres illustres du sunnisme primitif. Somme toute, c'était un éminent prédicateur qui recommandait vivement le bien et n'avait de cesse de guider les gens dans le chemin de la rectitude morale et de l'orthodoxie religieuse ${ }^{173}$. Sa réputation de saint homme était fort ancrée dans la mémoire collective des Bağdādiens, si bien qu'au moment de ses funérailles, qui donnèrent lieu à un cortège funèbre impressionnant, tous les souks de Bagdād furent fermés ${ }^{174}$. De toute évidence, avec Gulām Halîl, les traditionnistes étaient bien conscients qu'ils n'avaient pas affaire à un simple $z \bar{a} h i d$, tout bon à ranger dans la catégorie d'ascètes incultes ( $\breve{g} a h a l a t$ al-mutáabbidìn) tant décriés par eux.

Cependant, quand on en vient à la qualité de ses transmissions, toutes les collections d'avis critiques sans exception, s'accordent à n'y voir qu'un amas de hadiths inventés de toutes pièces, dépourvus de la moindre once

il vaudrait mieux éprouver la crainte de Dieu: al-ḩawf awlā binā, cf. al-Dahabī, Siyar, XIII, p. 284; C. Melchert, "The Hanābila », p. 360. D. Gril, dans «Les débuts du soufisme ", p. 37, écrit qu' "Abū l-Husayn al-Nūrī, au contraire, fait face et proclame sans réserve la légitimité de l'amour de Dieu. " Citons ici un passage tiré du livre K. Šarh al-sunna que l'on attribue à Gulām Halīl: wa-ḥdar an tağlisa máa man yad'ù ilā l-šawq wa-l-mahabba "Et prends garde à ne pas fréquenter quiconque prône le désir ardent et l'amour [de Dieu])», cf. L. Massignon, Recueil, p. 214.

171 Al-Dahabī, Mizzān, I, p. 142.

${ }^{172}$ Ibn al-Nadīm, Fibrist, p. 237: Kitāb al-Du'à', K. al-Inqițā̄ ilā llāh, K. al-Ṣalawāt, K. al-Mawāiz. L. Massignon lui attribue le Kitāb Šarh al-sunna [manuscrit, Damas, Zāhiriyya ("Mă̌ămī" ", 13)], d'où il tire plusieurs passages dont les Hanbalites font grand cas, cf. id., Recueil, p. 213; ainsi que F. Sezgin, GAS, I, p. 511.

173 Cf. Ibn Abī Hātim, Garh, II, p. 73; al-Ḍahabī, Siyar, XIII, p. 282-83. Il serait opportun, en effet, de mentionner que le grand juriste hanbalite Abū Muhammad al-Barbahārī (m. 329/941), dans son livre intitulé aussi $K$. Šarh al-sunna, avait emprunté textuellement à Gulām Halīl plusieurs passages, cf. L. Massignon, Recueil, p. 214. D’autre part F. Sezgin, dans GAS, I, p. 511, constate la même chose à propos d'Ibn Taymiyya, dans ses Mă̆mü al-rasäil al-kubrā. En dépit de la polémique actuelle autour de l'attribution du manuscrit de la Zāhiriyya (le $K$. Šarh al-sunna, ensemble $\mathrm{n}^{\circ} 13$, p. $1^{\mathrm{a}}-19^{\mathrm{b}}$ ) à Gulām Halīl, nous sommes plutôt enclin à penser que l'hypothèse de L. Massignon et de F. Sezgin n'est pas à exclure. Dans son article "The Hanābila ", p. 362, C. Melchert penche plutôt pour l'hypothèse contraire, et rappelle que Nevertheless, the document seems more likely to be al-Barbahärī's, not Gulàm Halìl's, for several reasons.

${ }_{174}$ Al-Bagdādī, Tảrīh, V, p. 80; Ibn al-Ğawzī, K. al-Mawdūèàt, I, p. 40; J. van Ess, Theologie, IV, p. 284. 
d'authenticité. Le recours de Gulām Halīl à l'invention des matns autant qu'à la fabrication des chaînes de garants a été dénoncé à travers maints anecdotes et récits où ses artifices de forgerie sont mis à nu par d'habiles critiques contemporains ${ }^{175}$. Toutefois, d'autres traditionnistes s'indigneront plus tard, non pas de savoir qu'il était un inventeur de hadiths qui diffusait des manākìr au sein de la communauté, mais surtout d'apprendre qu'en plus il confessait cela et ne s'en cachait nullement ${ }^{176}$. Parmi ceux-ci, il y a al-Dahabī qui exprime son indignation devant la persistance du personnage dans cette voie, et qui déplore son comportement outrageant. Après avoir énuméré les qualités religieuses de Gulām Halīl, al-Ḍahabī achève ses propos introductifs à la notice biographique qu'il lui a consacrée par cette conclusion, pointant d'un doigt accusateur ce trait fort fâcheux qui le caractérise: «[..] excepté que [...] il fut un adepte de l'invention de hadiths $»{ }^{177}$. Or une telle attitude de la part de Gulām Hualīl qui fait fi du formalisme de la transmission en matière de hadiths, s'apparente étroitement à une prise de position sur la légitimité même des règles de la riwāya. Sous ce rapport, cette position se donne à voir comme une des plus mauvaises actions d'un point de vue juridique, dans la mesure où elle entre en résonance avec le péché majeur de l'obstination dans la désobéissance à Dieu (al-iṣrār 'alā l-másisiya). Notons au passage qu'au jugement des experts traditionnistes, l'invention des hadiths, même à titre de stratagème habile dont la vocation principale serait l'éducation religieuse des musulmans, ne saurait être, eu égard aux conséquences désastreuses qu'elle pourrait entraîner, assimilée à une simple invention contingente, telle qu'en usaient les simples d'esprit parmi les renonçants ${ }^{178}$. D'après Ibn 'Adī (m. 365/976), lorsque Gulām Halīl avait été interrogé au sujet de quelques-uns des hadiths qu'il avait diffusés, afférents aux maux subtils de l'âme et à leurs remèdes spirituels $\left(r a q \vec{a}^{\vec{i}} q\right)$, il aurait répondu à son interlocuteur, non sans arborer une certaine fierté, que «[...] nous les [hadiths] avons sciemment

175 La plus souvent relatée est celle où il prétend avoir côtoyé, à Bașra, plus de soixante personnes qui répondaient toutes au nom de Bakr b. 'İsā. C'était évidemment là un subterfuge classique, largement usité par les forgeurs de hadiths, dont se servit Gulām Halīl pour faire croire qu'il en existait plusieurs, à son interlocuteur traditionniste de plus en plus circonspect, se demandant comment il eût pu connaître le véritable Bakr b. 'Īsā, transmetteur dont rapportaient les hommes de la génération d'Ibn Hanbal. Cf. al-Bagdādī, Tả rīh, V, p. 78-79; Ibn al-Ğawzī, K. al-Mawdūéàt, I, p. 40; al-Dahabī, Siyar, XIII, p. 284; id., Mìzān, I, p. 142; Ibn Hağar, Lisān, I, p. 237.

176 L. Massignon, Recueil, p. 213.

177 Al-Dahabī, Siyar, XIII, p. 283: [..] illā annahū yarā wad’ al-hadīt.

${ }_{178}$ Ibn al-Ğawzī n’a pas manqué de réserver une place de choix à Gulām Halīl, qu’il fait figurer dans le cinquième cas de la troisième partie de la cinquième catégorie intitulée «des menteurs invétérés", id., K. al-Mawdǖāt, I, p. 36-39. 
forgés dans le but louable d'adoucir les cœurs du commun des gens $\left(a l^{\prime}\right.$ àmma $) »^{179}$.

Ainsi y a-t-il suffisamment de témoignages contre lui pour que son contemporain, le hanbalite Abū Dāwud al-Siğistānī (m. 275/888), s'autorise de le surnommer l'Antéchrist de Bag̀dād (dăğgăl Bağdād). D'après lui, à l'issue d'une série d'examens pratiqués par ses soins, toutes les traditions transmises par Gulām Halīl se sont révélées, tant dans leurs isnāds que dans leurs matns, un énorme tissu de mensonges ${ }^{180}$. À la suite de ces condamnations sans appel, les critiques postérieurs le feront figurer dans le registre des garants marqués au fer rouge, ceux-là dont les hadiths doivent être formellement abandonnés ${ }^{181}$. Depuis, le nom de Gulām Halīl est devenu l'exemple type de l'excès et l'outrecuidance en matière de forgerie des traditions (wad' al-hadīt), dans les milieux sunnites à tendance ascétique.

Bien plus que les forgeurs de la génération précédente, ceux qui ont marqué celle-ci ont contribué plus rapidement à l'enrichissement de la zone de l'interpolation des traditions au sein de la science du hadith, en étendant la variété de ses thèmes à tous les domaines de la vie, et aux divers articles de la foi. Les deux mondes qui continuaient à cohabiter avaient de la peine à se croiser, à plus forte raison à se retrouver. D'un côté le monde de la tradition circonscrivant de plus en plus ses canaux de transmission, dans une intention d'exclusion manifeste, de l'autre celui des ascètes et dévots sans réels liens de transmission entre eux, qui se permettaient des intrusions, à titre participatif dirions-nous, dans le monde de ces derniers pour faire valoir leurs idées. Hormis que dans ce nouveau schéma qui a à peine évolué, la diffusion des enseignements de ces derniers gagnait en rapidité du fait de l'expansion du livre comme moyen de transmission du savoir. Quand ils décochaient leur critique contre Ibn Karrām ou Gulām Halīl, ce n'était pas seulement par ouï-dire que les critiques s'y employaient, mais en se référant, citations à l'appui, à leurs œuvres, qui leur étaient parvenues. Au troisième siècle de l'hégire, il va de soi que la démultiplication des ouvrages écrits, particulièrement en matière de religion, ne s'était pas faite pour déplaire aux $z u h h \bar{a} d$ et dévots qui s'y étaient engagés de plain-pied, mettant à contribution les traditions inventées de toute espèce. Avant d'être des transmetteurs qui faisaient l'objet de la

179 Al-Bag̀dādī, Tảrīh, V, p. 79; Ibn al-Ğawzī, K. al-Mawdī āt, I, p. 40; al-Dahabī, Siyar, XIII, p. 284; id., Mizzān, I, p. 141. L'interrogateur à qui Ibn 'Adī doit cette information est le traditionniste Abū 'Abd Allāh al-Nahāwandī.

180 Al-Baġdādī, Tảrīh, V, p. 79; al-Ḍahabī, Siyar, XIII, p. 283; C. Melchert, "The Hanābila", p. 361 .

${ }^{181}$ Cf. l'avis d'al-Dāraquṭnī: matrūk, in al-Ḍahabī, Mìzān, I, p. 142; Ibn Abī Ḥātim, Ğarḥ, II, p. 73. 
suspicion de leurs homologues traditionnistes, c'étaient d'abord des auteurs dont les œuvres répandaient des visions religieuses sur des lecteurs qui faisaient l'impasse sur la science du hadith, s'il n'en ignoraient pas même l'existence, cantonnée qu'elle fut alors dans sa sphère réduite de spécialistes. Le hadith, dans ces ouvrages, tend à redevenir instrument qui, comme autrefois avec al-Bașrīi, est appelé à servir une fin utile au sunnisme qu'il est temps maintenant de remodeler de l'intérieur pour l'ajuster aux doctrines nouvelles prônées par ces auteurs. À l'instar du sunnisme jadis, qui s'en était servi oralement comme moyen pour s'imposer face aux diverses factions religieuses rivales, les ascètes, notamment ceux enclins à la mystique, s'en servaient en toute bonne conscience de la même manière, oralement et par écrit, mais dans une entreprise qui avait pour ressort de se désolidariser, sur nombre de points religieux, du sunnisme traditionniste. Ce dernier qui en avait constitué la résultante institutionnelle, s'était laissé convaincre rétrospectivement qu'il ne recourait plus au hadith comme moyen, mais comme une fin en soi. Ceci dit, dans ces deux dispositions historiques, le hadith demeurait aux yeux des uns et des autres ce même produit de connaissance prisé, parce que redoublé de cette vertu lénifiante qui le caractérisait quand il s'agissait de faire passer pour religieux ce qui ne l'était pas encore et qui devrait le devenir. En cette troisième période, il nous faut être attentif à une instance nouvelle, qui vient s'inviter dans l'espace religieux savant, celle du Pouvoir politique qui brille par sa présence active dans ce débat entre innovateurs et conservateurs ascètes, respectivement encore Ibn Karrām et Gulām Hualīl. Sans en exagérer la portée, et tout en s'en tenant à des vues amples et imprécises que les matériaux historiques veulent bien permettre, on est amené aisément à reconnaître que la réputation des deux hommes n'aurait pu devenir un enjeu politicoreligieux qui avait nécessité l'intervention des détenteurs de l'autorité, sans qu'ils fussent aussi et surtout des auteurs dont les œuvres jouissaient d'une diffusion certaine. Cependant, dans les deux cas, l'intervention du pouvoir ne traduit pas l'acte de justice qui s'abat contre les forgeurs de hadiths, loin s'en faut; car, si elle a eu lieu c'est pour appuyer un camp contre un autre dans le mieux de ses intérêts où les considérations religieuses sont secondaires pour ne pas dire relativement absentes.

\section{Conclusion}

À considérer de près les raisons avancées par ces ascètes garants de hadiths pour justifier leur initiative frauduleuse dans la transmission des traditions, depuis l'époque des fondateurs jusqu'à celle des Suivants de la troisième géné- 
ration, il appert que les bonnes intentions y tiennent lieu d'un invariant. L'enjeu est donc d'ordre téléologique, consistant dans ce désir exprimé comme volonté de participer au bien de la communauté, mais qui passe nécessairement par la propagande au moyen de la tradition. Nous avons vu que le premier succès du sunnisme n'était pas tout à fait étranger à l'éclosion de cette espèce de transmetteurs qui excipaient de leur fidélité aux enseignements de leurs prédécesseurs de quoi se livrer ingénument à l'invention des traditions. Au contraire, il y aurait lieu de voir, dans le laxisme qui caractérisait la transmission des traditions chez certains personnages clés du sunnisme primitif, une source d'inspiration pour les ascètes forgeurs de hadiths ultérieurs. La grande part dans cette entreprise de forgerie revient, sans conteste, aux rapporteurs d'origine bașrienne. C'est à Bașra, rappelons-le, que le noyau constitutif du sunnisme primitif a pris naissance, et c'est également aux traditionnistes de cette ville que l'on doit le grand intérêt porté au zuhd ainsi qu'à la stricte morale religieuse à travers la riwāya. Après tout, ils ne visaient à leur tour que ces mêmes grands principes moraux auxquels avaient appelé jadis leurs prédécesseurs. À cette différence près toutefois, qu'ils ne visaient plus à harmoniser les diverses composantes de la communauté musulmane, dans la mesure où leur terrain d'action se limitait à la communauté sunnite, qu'ils tendaient à instruire et à éduquer de l'intérieur. De même que les pieux Anciens avaient eu en vue l'unité de la communauté alors au bord de l'éclatement, de même plus tard ces garants de hadiths visaient par le truchement de leurs enseignements un idéal non moins louable qui leur faisait concevoir bénéfique l'utilité urgente de leur intervention. Certains d'entre eux qui avouaient être motivés par une noble raison morale qui participe de l'instruction religieuse de leurs coreligionnaires, ne percevaient pas du tout l'invention des hadiths comme une mauvaise action sui generis. On voit comment l'argument religieux qu'incarnent dorénavant les traditions prophétiques est devenu un moyen de persuasion d'autant plus efficace que l'on a fini par céder à la tentation de la transmission mensongère. Autrement dit, cela équivaudrait à laisser l'avantage aux adversaires du sunnisme, et d'être, soit à la discrétion de leur propagande sans scrupules, soit à celle des ruwāt sunnites suspects qui ne valaient guère mieux, eu égard à leurs hadiths souvent décriés au sein des rapporteurs de récits (abbäriyyūn) et de conteurs publics $(q u s s \bar{a} \bar{a})^{182}$.

182 Parmi ceux le plus souvent cités, il est un faussaire notoire du nom d'Abū 'Ișma l-Ğāmi Nūḥ b. Abī Maryam. Il aurait avoué avoir forgé une impressionnante quantité de hadiths qu’il faisait remonter pour la plupart au Suivant 'Ikrima mawlā d'Ibn 'Abbās (m. 105/722). Ces hadiths incitent à la lecture du Coran et informent par le menu des rétributions du croyant pour la lecture de certains versets et sourates coraniques. Abū 'Ișma avouait avoir œuvré ainsi 
En effet, ayant gagné presque toutes les aires culturelles du monde musulman dès le début du II $/$ VIII ${ }^{e}$ siècle, le hadith acquérait le statut de principe du droit. Par l'instigation d'autorités traditionnistes, soutenues par des juristes partisans des abl al-ḥadīt, à l'instar d'al-Šâfi î (m. 204/820), le hadith s'était imposé peu à peu vers la fin du deuxième et le début du troisième siècle (II $\left.{ }^{e}-I_{I} / I^{e} / X^{e}\right)$ comme deuxième source scripturaire de l'Islam. En secondant la parole de Dieu (Coran) la tradition prophétique réussit une conquête de premier ordre qui témoigne du triomphe majeur du traditionnisme. Dès lors, l'on ne comprend que trop bien pourquoi, par voie de conséquence, d'autres disciplines corrélatives à finalité critique devaient voir le jour. D'une part, parce qu'il est vrai que le contexte historique de la culture religieuse musulmane se prêtait largement à cette tournure des événements en faveur de ce triomphe final, et d'autre part parce qu'il s'agissait d'affermir le hadith dans sa valeur de source juridico-morale, objectif qui impliquait l'élaboration d'un système de contrôle entièrement dévolu à l'évaluation de la véracité des matns ('ilal al-ḥadīt) aussi bien qu'à la fiabilité et l'intégrité de l'ensemble des rapporteurs figurant dans les chaînes de transmission, à savoir la «critique des autorités" ( $i l m$ al-riğ $\bar{a} l$ ).

Or, nul doute que c'est grâce à cette dernière branche des sciences du hadith que nous sommes amplement renseignés sur cette catégorie de transmetteurs dont le recours à la forgerie de hadiths n'était pas dû spécialement aux conflits doctrinaux, ni aux rivalités, politique, raciale ou clanique, qui sévissaient à leur époque. En ce qui les concerne, nous l'avons vu, il ne s'agissait pas, dans les dissidences intestines, de prendre parti pour telle ou telle secte religieuse comme le ší isme ${ }^{183}$ ou le huāriğisme ${ }^{184}$, ni de prêter main forte

dans la pieuse intention de plaire à Dieu (hisbatan). En répandant ces hadiths, il entendait ramener à Dieu tous les fidèles égarés qui se sont détournés de Sa parole au profit de la jurisprudence d'Abū Hanīfa (m. 150/767) et des récits d'expéditions militaires du Prophète (mäḡāzi) rapportées par Ibn Isḥāq (m. 150/767). Cf. Ibn al-Gawzī, K. al-Mawdūeàt, I, p. 41; I. Goldziher, Etudes sur la tradition, p. 192 [Muhammedanische Studien, II, p. 156].

183 Il se trouve des transmetteurs qualifiés de non sûrs pour avoir adopté des thèses šĩ ites, comme le savant šicite Ğābir b. Yazīd al-Ğưfī l-Kūfī (m. 127/745), cf. Muslim, Ṣaḥịh, I, p. 20, 21; al-Dahabī, «Dikr man yu tamadu qawluhu», in Arba rasäill, p. 174. Sur les Rāfiḍa (Šìi ites extrémistes), voir Ibn al-Ğawzī, Talbis, p. 97-101; sur les quelques exemples de hadiths qu'ils ont forgés, cf. id., K. al-Mawd̄̄̄ät, I, p. 338-402.

184 Voir Ibn al-Ğawzī, Talbìs, p. 99 sq., sur les hadiths forgés par les Hāriğites. Si l'on prend l'exemple de 'Abd al-Rahmān b. Mulğim al-Murādī (m. 40/661), le Hāriğite qui assassina le quatrième calife 'Alī b. Abī Țālib en l'an 40/661, on note qu'il fut un fervent croyant extrêmement pieux, et d'une grande rigueur ascétique. Cependant, toute sa transmission fut d'emblée rejetée en raison de son acte d'assassinat, exécuté par fidélité aux principes politiques et religieux du hāriğisme, cf. al-Ḍahabī, Mìzān, III, p. 592; aussi id., "Dikr man», p. 174; Ibn Hağar, Lisān, III, p. 439-40. 
à telle ou telle doctrine théologique contre une autre comme le qadarisme ${ }^{185}$ ou le murği isme par exemple ${ }^{186}$. Ils ne se tenaient pas non plus dans le sillage des forgeurs antérieurs, qui empruntaient expressément cette voie à des fins personnelles, sinon dans l'intention avouée de faire l'apologie de leurs chefs religieux ou de vanter les mérites de leur école juridique ou théologique au détriment de celle de leurs rivaux ${ }^{187}$. Dans les nombreux témoignages que nous avons évoqués, il ressort sans doute qu'à l'origine de cette démarche, il y avait bel et bien un sincère sentiment de piété religieuse qui se donnait pour dessein le seul bien de la communauté. En revanche, avec les personnages clés de la deuxième génération nous sommes en présence d'un type de zuhhād qui, bien conscients de l'illégalité de leur pratique, persistaient mordicus dans l'invention des hadiths. Mais avec les renonçants de la troisième génération, semble venir le temps des forgeurs qui, en dépit de la condamnation de cette pratique par leurs contemporains traditionnistes, s'empressaient d'en faire une orientation personnelle sciemment revendiquée à seule fin de satisfaire aux besoins urgents d'un impératif communautaire pressant d'ordre éducatif et spirituel. Ainsi, en un siècle et demi d'intervalle environ, d'un tadlīs

185 On citera, à titre d'exemple, l'un des plus grands forgeurs de hadiths de son époque, Muḥammad b. 'Ukāša b. Muḥsin al-Kirmānī (cf. Ibn al-Ğawzī, K. al-Mawdū̄āat, I, p. 46) qui faisait répandre des traditions dans lesquelles il professait la doctrine qadarite. Il rapportait que le Prophète aurait dit: "Celui qui ne croit pas au décret divin (al-qadar) ne fait pas partie des miens " (cf. Ibn Abī Ḥātim, Garh, VIII, p. 52, n 238; Ibn 'Asākir, Ta’rīh Dimašq, LIV, p. 229, $\mathrm{n}^{\circ}$ 6758). Sur le qadarisme voir J. van Ess, Zwischen Hadit und Theologie. Studien zum Entstehen prädestinatianischer Überlieferung, Berlin, New York, Walter de Gruyter, 1975, surtout "Qadaritische und antiqadaritische Varianten des "Sekten hadītes" ", p. 134-7.

186 Muhammad b. al-Qāsim al-Ṭālikānī (ou al-Ṭāliqānī), «était un des parangons des Murği ites, écrit Ibn al-Ğawzī, qui forgeait des hadiths en conformité avec leur doctrine théologique ", cf. id., K. al-Mawdǖät, I, p. 39; aussi Burhān al-Dīn, al-Kašf, p. 400, n 718, où son nom est vocalisé par erreur al-Ṭāyikānī.

187 Voir L. Massignon, Essai, p. 120. Il y avait aussi des forgeurs de hadiths qui recouraient à la forgerie uniquement pour vanter les qualités de leurs propres maitres, et quelquefois de leurs imams favoris. Parmi eux, il y a un certain Ma’mūn b. Aḥmad al-Sulamī l-Harawī, forgeur de hadiths notoire, bien connu des spécialistes de la critique des riğăl (cf. Ibn 'Asākir, Tàrīh Dimašq, LVII, p. 3-6, n 7195). Il avait rapporté la tradition suivante dans laquelle il fait l'éloge d'Abū Hanīfa aux dépens d'al-Šăfí̄: «Il y aura dans ma communauté un homme répondant au nom de Muhammad b. Idrīs [al-Šāfíī], il sera plus néfaste pour ma communauté que ne l'est satan $(I b l i \bar{s})$, de même y aura-t-il un homme répondant au nom d'Abū Hanīfa, c'est lui le flambeau de ma communauté», cf. al-Dahabī, Mizānn, III, p. 430, n 7036.

Une autre version de ce hadith est attribuée à l'un des plus célèbres forgeurs dans l'histoire de la transmission des traditions, par le biais d'Ibn Karrām, Aḥmad (plutôt que Hamīd) b. 'Abd Allāh al-Ğuwaybārī, qui le met dans la bouche du compagnon Anas b. Mālik (m. 92/711): " [...] Abū Hanīfa, par l'intermédiaire de qui Dieu renouvellera ma tradition", cf. al-Dahabī, Mizān, I, p. 108. Voir aussi sur le procédé de la double forgerie, abondamment pratiquée par al-Ğuwaybārī, la vaste notice critique que lui a consacré Ibn Hağar dans son Lisān, I, p. 193-4, $\mathrm{n}^{\circ} 611$. 
hésitant et maladroit à peine déguisé auquel s'adonnaient quelques Suivants ascètes et dévots on passe progressivement à une forgerie ( $\mathrm{wad}^{\prime}$ ) consciencieusement préparée par les soins d'acteurs ascètes déterminés à en faire abusivement usage à telle enseigne qu'ils s'en réclamaient de vive voix. À toute quête sa logique intrinsèque, faut-il se priver en religion d'un redoutable moyen aussi efficace que celui-ci pour contribuer à la consolidation de la Umma? Telle fut probablement la question à laquelle les forgeurs, parmi les dévots et les ascètes, s'étaient proposés de répondre par la négative en optant pour l'invention des hadiths. Phénomène des plus ordinaires, comme dans toute littérature, dont on doit rendre justice à Maurice Blanchot lorsqu'il écrit à juste titre: «Fictions, Artifices risquent d'être les noms les plus honnêtes que la littérature puisse recevoir [..] nous pensons que s'il y a falsification universelle, c'est encore au nom d'une vérité peut-être inaccessible, mais vénérable et, pour certains, adorable ${ }^{188}$." 